\title{
Superoxide is the major reactive oxygen species regulating autophagy
}

\author{
Y Chen $^{1,2}$, MB Azad $^{1,2}$ and SB Gibson ${ }^{*, 1,2}$
}

\begin{abstract}
Autophagy is involved in human diseases and is regulated by reactive oxygen species (ROS) including superoxide $\left(\mathrm{O}_{2}^{{ }^{-}}\right)$and hydrogen peroxide $\left(\mathrm{H}_{2} \mathrm{O}_{2}\right)$. However, the relative functions of $\mathrm{O}_{2}^{--}$and $\mathrm{H}_{2} \mathrm{O}_{2}$ in regulating autophagy are unknown. In this study, autophagy was induced by starvation, mitochondrial electron transport inhibitors, and exogenous $\mathrm{H}_{2} \mathrm{O}_{2}$. We found that $\mathrm{O}_{2}^{*-}$ was selectively induced by starvation of glucose, L-glutamine, pyruvate, and serum (GP) whereas starvation of amino acids and serum (AA) induced $\mathrm{O}_{2}^{--}$and $\mathrm{H}_{2} \mathrm{O}_{2}$. Both types of starvation induced autophagy and autophagy was inhibited by overexpression of SOD2 (manganese superoxide dismutase, Mn-SOD), which reduced $\mathrm{O}_{2}^{--}$levels but increased $\mathrm{H}_{2} \mathrm{O}_{2}$ levels. Starvation-induced autophagy was also inhibited by the addition of catalase, which reduced both $\mathrm{O}_{2}^{--}$and $\mathrm{H}_{2} \mathrm{O}_{2}$ levels. Starvation of GP or AA also induced cell death that was increased following treatment with autophagy inhibitors 3-methyladenine, and wortamannin. Mitochondrial electron transport chain (mETC) inhibitors in combination with the SOD inhibitor 2-methoxyestradiol (2-ME) increased $\mathrm{O}_{2}^{--}$levels, lowered $\mathrm{H}_{2} \mathrm{O}_{2}$ levels, and increased autophagy. In contrast to starvation, cell death induced by mETC inhibitors was increased by 2-ME. Finally, adding exogenous $\mathrm{H}_{2} \mathrm{O}_{2}$ induced autophagy and increased intracellular $\mathrm{O}_{2}^{--}$but failed to increase intracellular $\mathrm{H}_{2} \mathrm{O}_{2}$. Taken together, these findings indicate that $\mathrm{O}_{2}^{--}$is the major ROS-regulating autophagy.

Cell Death and Differentiation (2009) 16, 1040-1052; doi:10.1038/cdd.2009.49; published online 1 May 2009
\end{abstract}

Autophagy is a lysosomal degradation process characterized by the formation of double-membraned autophagosomes. During autophagy, cytoplasmic material and organelles are sequestered by an isolation membrane derived from the preautophagosomal structure. Fusion of this double-membraned vesicle creates an autophagosome, which ultimately fuses with a lysosome. Within the resulting autophagolysosome, the sequestered cytoplasmic materials are degraded by acidic hydrolases. Autophagic degradation generates amino acids and fatty acids that can be used for protein synthesis or oxidized through the mitochondrial electron transport chain (mETC) to produce ATP for cell survival under starvation conditions. ${ }^{1}$ However when autophagy is prolonged, proteins and organelles essential for basic homeostasis and cell survival are degraded, which can lead to cell death (autophagic cell death or programmed cell death type II, PCD II). ${ }^{2}$ Therefore, autophagy is both a cell survival mechanism and a cell death pathway depending on the extent of cellular degradation.

Reactive oxygen species (ROS) are molecules or ions that are formed by the incomplete one-electron reduction of oxygen. The major species of ROS include superoxide $\left(\mathrm{O}_{2}^{{ }^{-}}\right)$, hydrogen peroxide $\left(\mathrm{H}_{2} \mathrm{O}_{2}\right)$, and hydroxyl radical $\left({ }^{\circ} \mathrm{OH}\right){ }^{3}$ These three major ROS are mainly produced through a chain reaction as follows: $\mathrm{O}_{2}^{--}$, which is mainly produced from mETC complexes I and III, is converted to $\mathrm{H}_{2} \mathrm{O}_{2}$ by the superoxide dismutase (SOD) family of enzymes, which mainly include SOD1 (copper-zinc superoxide dismutase, $\mathrm{Cu}, \mathrm{Zn}-\mathrm{SOD}$ ) and SOD2 (manganese superoxide dismutase, $\mathrm{Mn}-\mathrm{SOD}$ ). $\mathrm{H}_{2} \mathrm{O}_{2}$ can then be converted to ${ }^{\circ} \mathrm{OH}$ by ferrous iron $\left(\mathrm{Fe}^{2+}\right)$ or copper ion $\left(\mathrm{Cu}^{+}\right)$, or it can be catalyzed to $\mathrm{H}_{2} \mathrm{O}$ by catalase, glutathione peroxidase (GPx) and peroxiredoxin III (PrxIII). ${ }^{3}$ Thus, the levels of $\mathrm{O}_{2}^{\bullet-}, \mathrm{H}_{2} \mathrm{O}_{2}$, and ${ }^{\bullet} \mathrm{OH}$ are constantly in flux until an equilibrium is established.

It is well known that ROS can regulate apoptosis (PCD type I). ${ }^{4}$ ROS regulation of autophagy has also been demonstrated in many reports. ${ }^{5-22}$ Most of these studies have implicated ROS in autophagy induction by using nonspecific ROS scavengers or exogenous $\mathrm{H}_{2} \mathrm{O}_{2} \cdot{ }^{5,7-9,12,14,21}$ Our previous studies suggest that $\mathrm{O}_{2}^{\bullet-}$ specifically mediates autophagy induced by mETC inhibitors (complex I inhibitor rotenone and complex II inhibitor 2-thenoyltrifluoroacetone (TTFA)), the SOD inhibitor 2-methoxyestradiol (2-ME), ${ }^{23}$ and exogenous $\mathrm{H}_{2} \mathrm{O}_{2} \cdot{ }^{3,17,18} \mathrm{Kim}$ et al. ${ }^{13}$ have demonstrated that sodium-selenite-induced autophagy is also regulated by $\mathrm{O}_{2}^{\bullet-}$. In contrast, several reports have specifically implicated $\mathrm{H}_{2} \mathrm{O}_{2}$ in regulating autophagy. ${ }^{11,16,19,20,22}$ Thus, it seems that both $\mathrm{O}_{2}^{\bullet-}$ and $\mathrm{H}_{2} \mathrm{O}_{2}$ are involved, however none of the previous

\footnotetext{
${ }^{1}$ Manitoba Institute of Cell Biology, University of Manitoba, Winnipeg, Manitoba, Canada and ${ }^{2}$ Department of Biochemistry and Medical Genetics, Faculty of Medicine, University of Manitoba, Winnipeg, Manitoba, Canada

${ }^{*}$ Corresponding author: SB Gibson, Manitoba Institute of Cell Biology, University of Manitoba, 675 McDermot Ave, Winnipeg, Manitoba R3E 0V9, Canada.

Tel: + 204787 2051; Fax: + 204787 2190; E-mail: gibsonsb @cc.umanitoba.ca

Keywords: autophagy; superoxide; superoxide dismutase; reactive oxygen species; starvation; mitochondrial electron transport chain

Abbreviations: AA, amino acids and serum; AO, acridine orange; AVOs, acidic vesicular organelles; CM-H2DCFDA, 5-(and-6)-chloromethyl-2', $7^{\prime}$-dichlorodihydrofluorescein diacetate acetyl ester; DHE, dihydroethidium; 2-ME, 2-methoxyestradiol; 3-MA, 3-methyladenine; GFP, green fluorescent protein; GP, glucose, L-glutamine, pyruvate and serum; GPx, glutathione peroxidase; $\mathrm{H}_{2} \mathrm{O}_{2}$, hydrogen peroxide; LC3, microtubule-associated protein 1 light chain 3; mETC, mitochondrial electron transport chain; $\mathrm{NAC}, \mathrm{N}$-acetyl-cysteine; $\mathrm{O}_{2}^{\bullet-}$, superoxide; ${ }^{\circ} \mathrm{OH}$, hydroxyl radical; $\mathrm{PCD}$, programmed cell death; PrxllI, peroxiredoxin III; ROS, reactive oxygen species; SOD, superoxide dismutase; SOD1, copper-zinc superoxide dismutase ( $\mathrm{Cu}, \mathrm{Zn}-\mathrm{SOD}$ ); SOD2, manganese superoxide dismutase (Mn-SOD); TTFA, 2thenoyltrifluoroacetone

Received 31.10.08; revised 23.3.09; accepted 25.3.09; Edited by D Klionsky; published online 01.5 .09
} 
studies has investigated the relative functions of both species in the regulation of autophagy. Thus, the ROS responsible for regulating autophagy remains unclear.

In this study we have investigated the relative functions of $\mathrm{O}_{2}^{\bullet-}$ and $\mathrm{H}_{2} \mathrm{O}_{2}$ in autophagy induced by starvation, mETC inhibitors, and exogenous $\mathrm{H}_{2} \mathrm{O}_{2}$. We found that the levels of autophagy induced by starvation, mETC inhibition, and exogenous $\mathrm{H}_{2} \mathrm{O}_{2}$ correlated with increased $\mathrm{O}_{2}^{\bullet-}$ levels and decreased $\mathrm{H}_{2} \mathrm{O}_{2}$ levels. Furthermore, starvation-induced cell death was increased by the inhibition of autophagy with autophagy inhibitors and $\mathrm{O}_{2}^{\bullet-}$ scavengers but decreased by the enhancement of autophagy by knocking down SOD2 expression. In contrast, cell death induced by mETC inhibitors was elevated by the enhancement of autophagy with SOD2 inhibition. These results give significant insights into the regulation of autophagy.

\section{Results}

Starvation induces ROS generation. Several reports have suggested that starvation-induced autophagy is mediated by ROS. $^{5-22}$ In this study, we investigated the generation of $\mathrm{O}_{2}^{\bullet-}$ and $\mathrm{H}_{2} \mathrm{O}_{2}$ under two starvation conditions: starvation of glucose, L-glutamine, pyruvate, and serum (GP), and starvation of amino acids and serum (AA). Cellular levels of $\mathrm{O}_{2}^{\bullet-}$ and $\mathrm{H}_{2} \mathrm{O}_{2}$ were measured by flow cytometry using specific fluorescent dyes (see Materials and Methods). Figure 1 shows that over a 72-h time course in HeLa cells, GP or AA starvation increased $\mathrm{O}_{2}^{\bullet-}$ levels to $50 \%$ compared with $10 \%$ in control conditions (also Supplementary Figure S1). GP starvation did not induce $\mathrm{H}_{2} \mathrm{O}_{2}$ generation (Figure 1a) whereas AA starvation induced $\mathrm{H}_{2} \mathrm{O}_{2}$ generation up to $80 \%$ (Figure $1 \mathrm{~b}$; Supplementary Figure S1). Generation of $\mathrm{O}_{2}^{\bullet-}$ and $\mathrm{H}_{2} \mathrm{O}_{2}$ was not significant before $6 \mathrm{~h}$ of starvation. Similar results were also obtained in U87 cells (Supplementary Figure S2) and HEK293 cells (data not shown). Thus, both GP and AA starvation increased $\mathrm{O}_{2}^{\bullet-}$ levels but only $A A$ starvation increased $\mathrm{H}_{2} \mathrm{O}_{2}$ levels.

Starvation induces autophagy. It is well known that starvation can induce autophagy. ${ }^{1}$ In this study, we detected starvation-induced autophagy using three methods as in our previous studies. ${ }^{17,18,24}$ We transiently transfected cells with GFP-LC3, which is recruited to autophagosome membranes during autophagy resulting in a punctate distribution that can be visualized using a fluorescent microscope. We measured the formation of acidic vesicular organelles (AVOs, which include autolysosomes) by flow cytometry using the $\mathrm{pH}$ sensitive fluorescent dye acridine orange (AO). Finally, we used western blotting to detect the conversion of cytosolic LC3-I to lipidated, autophagosome-membrane-bound LC3-II. Because LC3-II is continually degraded within autophagolysosomes during autophagy, it is recommended that cells be treated with a lysosomal inhibitor before western blotting for LC3-II to demonstrate autophagic flux. ${ }^{25,26}$ In the presence of the lysosomal inhibitor $\mathrm{NH}_{4} \mathrm{Cl}$, GP or AA starvation in HeLa cells induced elevated levels of LC3-II at 24 and $48 \mathrm{~h}$ but not at 1 and $6 \mathrm{~h}$ (Figure 2a), correlating with ROS generation (Figure 1). Similar phenomena were also observed in U87

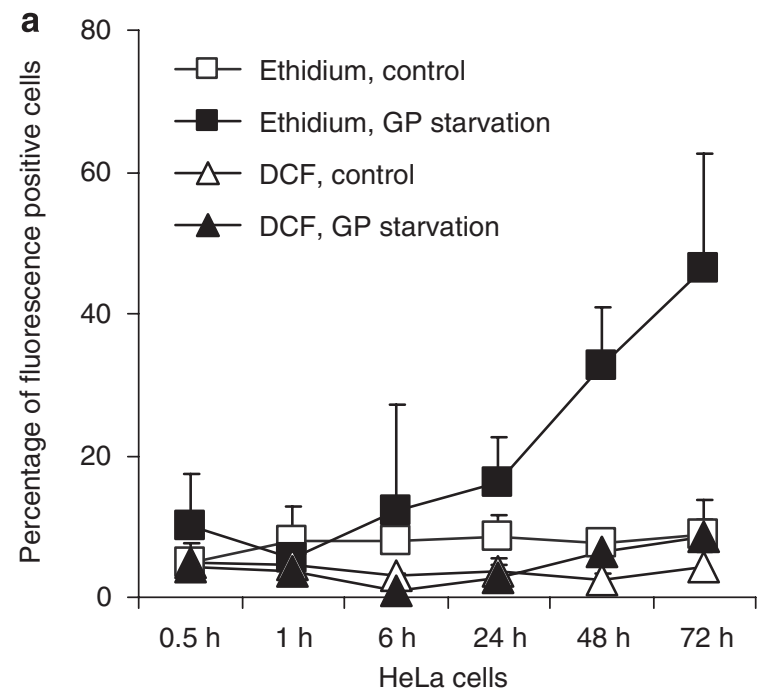

b

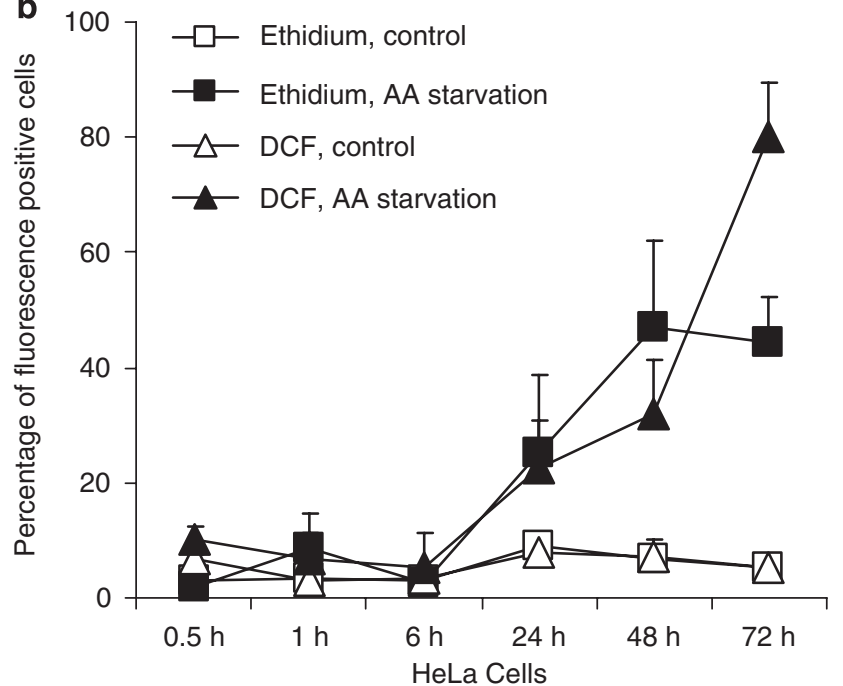

Figure 1 Starvation induces ROS generation in HeLa cells over a 72-h time course. (a) Starvation of GP (glucose, L-glutamine, pyruvate, and serum). (b) Starvation of AA (amino acids and serum). Intracellular $\mathrm{O}_{2}^{\bullet-}$ and $\mathrm{H}_{2} \mathrm{O}_{2}$ were measured by flow cytometry after cells were stained with DHE (dihydroethidium) and CM-H2DCFDA (5-(and-6)-chloromethyl-2' $7^{\prime}$-dichlorodihydrofluorescein diacetate acetyl ester), respectively, as stated in Materials and Methods section. Because DHE is oxidized to ethidium by $\mathrm{O}_{2}^{\bullet-}$ and CM-H2DCFDA is oxidized to DCF (dichlorofluorescein) by $\mathrm{H}_{2} \mathrm{O}_{2}$, the percentages of ethidium fluorescence and DCF fluorescence represent the levels of intracellular $\mathrm{O}_{2}^{\bullet-}$ and $\mathrm{H}_{2} \mathrm{O}_{2}$, respectively. Error bars represent standard deviation (S.D.) from three independent duplicate experiments

cells (Supplementary Figure S3). Starvation of GP or AA also induced the formation of GFP-LC3 puncta (Figure 2b) and AVOs (Figure 2c) in HeLa cells. Elevated amount of starvation-induced LC3-II and microtubule-associated protein 1 light chain 3 (LC3) puncta could be observed as early as at $24 \mathrm{~h}$ (Figure $2 \mathrm{a}$ and $\mathrm{b}$ ) whereas elevated amount of starvation-induced AVOs could only be seen after $48 \mathrm{~h}$ (Figure 2c). This supports the current hypothesis that the formation of autolysosomes (which belong to AVOs) lags behind the formation of autophagosomes. ${ }^{1}$ In the presence of 3-methyladenine (3-MA, a chemical inhibitor of 
autophagy), starvation-induced LC3-II formation was significantly reduced (Figure 2d). 3-MA treatment also decreased starvation-induced formation of GFP-LC3 puncta and AVOs in HeLa cells: the percentage of GP or AA starved cells with GFP-LC3 puncta was reduced from 40 to $14 \%$, whereas the percentage of cells with AVOs decreased from 33 to $2 \%$ (GP starvation), and from 18 to $2 \%$ (AA starvation) (Supplementary Figure S4a). Wortmannin, another autophagy inhibitor, decreased the percentage of cells with AVOs from 45 to $11 \%$ with GP starvation and from 37 to $6 \%$ with AA starvation (Supplementary Figure S4bi). Furthermore, when the autophagy genes beclin- 1 and atg-7 were knocked down by siRNA in HeLa cells (Figure 2ei), starvation-induced LC3-II formation was reduced (Figure 2eii), and the percentage of cells with AVOs was reduced from 30 to $9 \%$ with GP starvation and from 23 to $2 \%$ with $A$ A starvation (Supplementary Figure S4c). GFP-LC3 puncta was also reduced from 40 to $15 \%$ with GP starvation and from 34 to $13 \%$ with AA starvation (Supplementary Figure S4c). Therefore, both GP and AA starvation conditions induce autophagy to similar extents.

Under starvation conditions, autophagy is normally considered to be a cell survival mechanism. ${ }^{1}$ To test this hypothesis, we investigated the effect of autophagy inhibition on

a

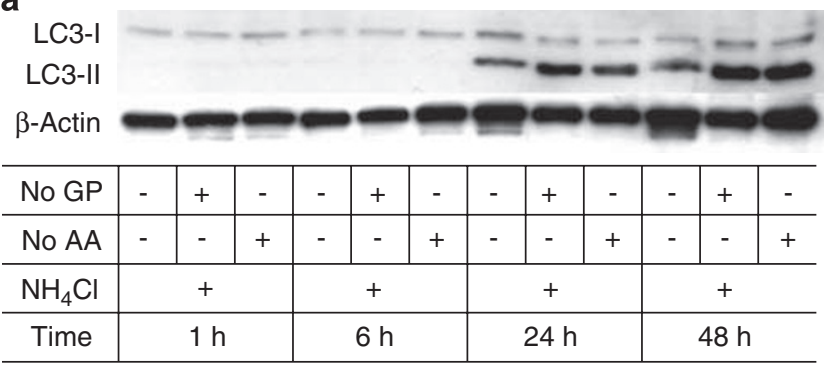

C

-.. Control — No GP
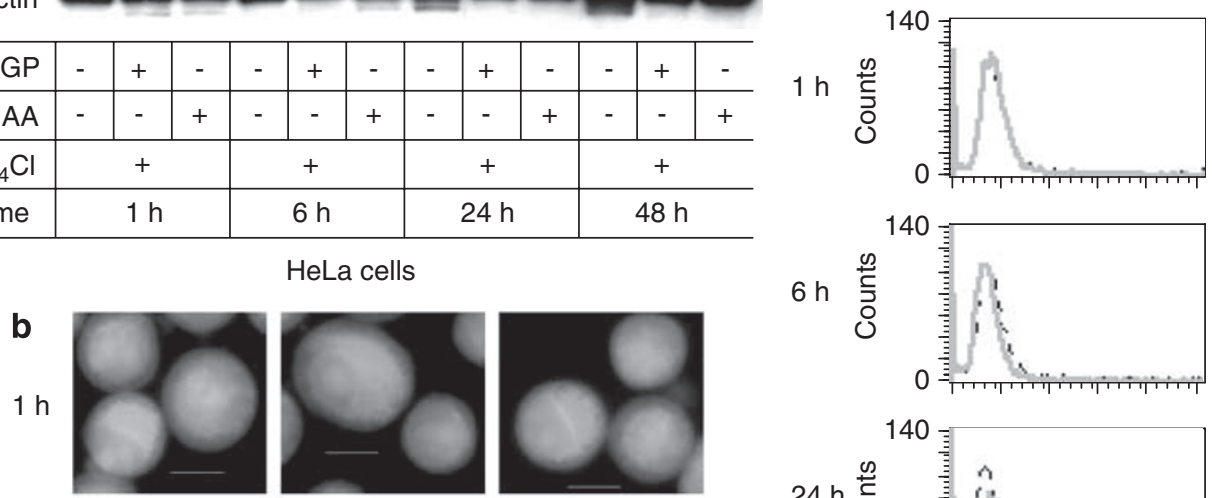

HeLa cells
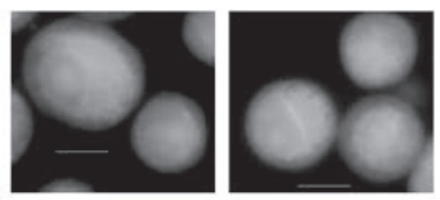

$6 \mathrm{~h}$
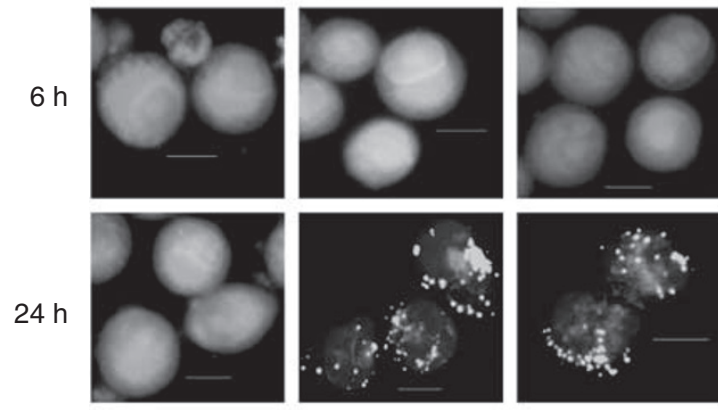

$48 \mathrm{~h}$
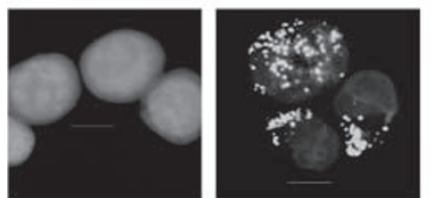

GP starvation

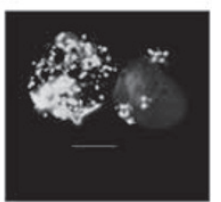

AA starvation
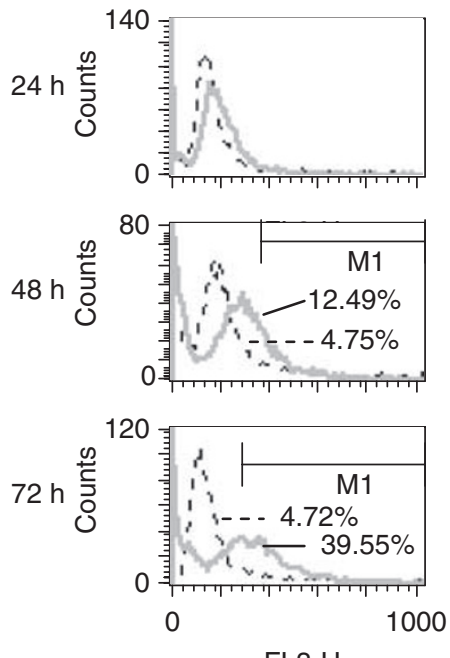

FL3-H
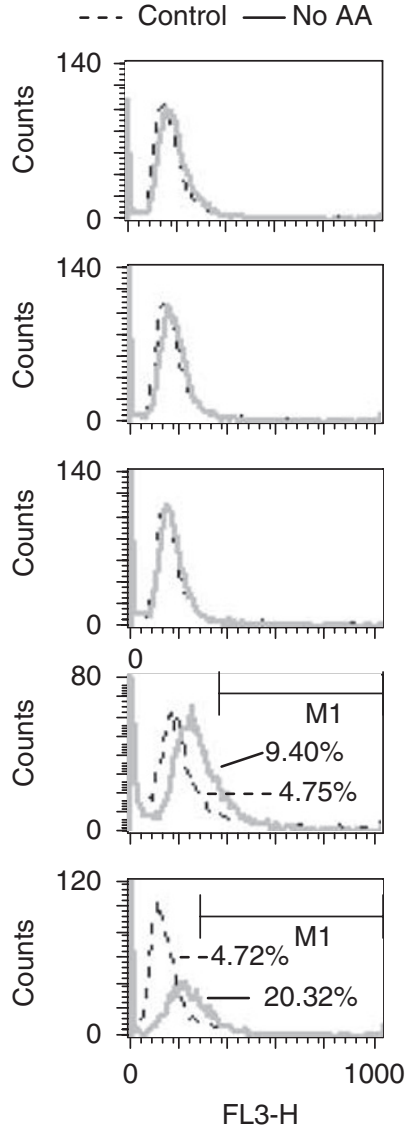

HeLa cells

Figure 2 Starvation induces autophagy and cell death in HeLa cells. (a) Formation of LC3-Il after cells were starved of GP or AA for 1, 6, 24, and 48 h. (b) Representative fluorescent microscopic figures of the formation of GFP-LC3 dots (puncta) after cells were transfected with GFP-LC3 CDNA and starved of GP or AA for 1, 6, 24, and 48 $\mathrm{h}$. GFP-LC3 dots were not observed when cells were transfected with GFP cDNA (data not shown). Scale bars $=10 \mu \mathrm{m}$. (c) Representative histographs of AVOs formation analyzed by flow cytometry after cells were starved of GP or AA for 1, 6, 24, 48, and $72 \mathrm{~h}$. The gated region (M1) in each histogram represents the percentage of cells with AVOs. (d) Effect of autophagy inhibitor 3-MA (2 mM) on formation of LC3-II after cells were starved of GP or AA for $48 \mathrm{~h}$. (e) Effect of beclin-1 and atg-7 siRNAs on formation of LC3-Il after cells were starved of GP or AA for $48 \mathrm{~h}$. (i) Expression of beclin-1 and ATG-7 after cells were transfected with control, beclin-1 and atg-7 siRNAs. (ii) Western blot showing formation of $\mathrm{LC} 3-I I$ with $\beta$-actin used as a loading control. Cells were treated with the lysosomal inhibitor $\mathrm{NH}_{4} \mathrm{Cl}$ at $30 \mathrm{mM}$ for the determination of autophagy flux. (f) Cell death induced by GP or AA starvation. Cell death was analyzed by measuring the plasma membrane permeability by flow cytometry using Trypan blue to stain cells as described in Materials and methods section. The percentage of plasma membrane permeability represents the percentage of cell death. (i) Cell death induced by GP and AA starvation in a 72-h time course. (ii) Effect of 3-MA (2 mM) on GP or AA starvation-induced cell death at 24, 48, and $72 \mathrm{~h}$. (iii) Effect of beclin-1 and atg-7 siRNAs on GP or AA starvation-induced cell death at $72 \mathrm{~h}$. All data are representative of three independent experiments 


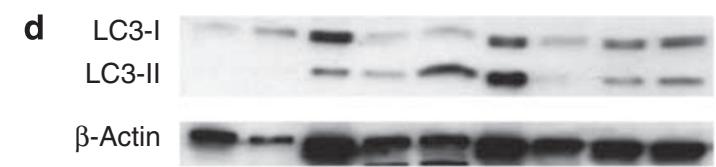

\begin{tabular}{c|c|c|c|c|c|c|c|c|c}
\hline No GP & - & + & - & - & + & - & - & + & - \\
\hline No AA & - & - & + & - & - & + & - & - & + \\
\hline 3-MA & \multicolumn{1}{|c|}{$48 \mathrm{~h}$} \\
\hline $\mathrm{NH}_{4} \mathrm{Cl}$ & \multicolumn{1}{|c}{-} & \multicolumn{3}{|c}{+} & \multicolumn{2}{|c}{+} \\
\hline Time (h) & \multicolumn{1}{|c}{+} \\
\hline
\end{tabular}

HeLa cells

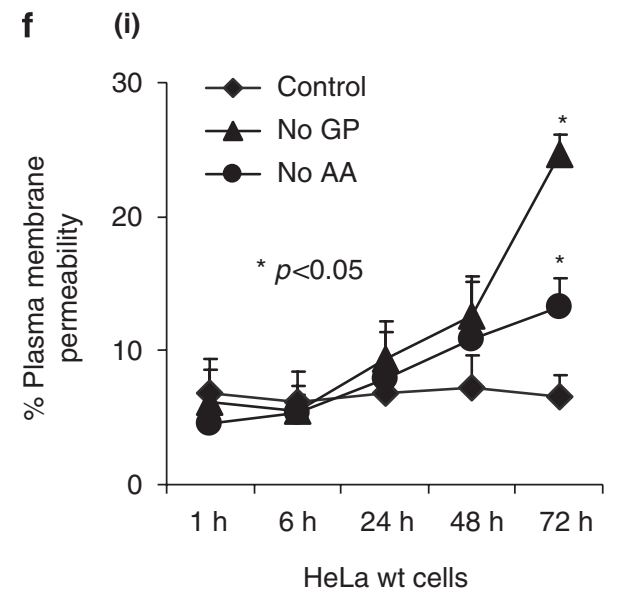

e (i)

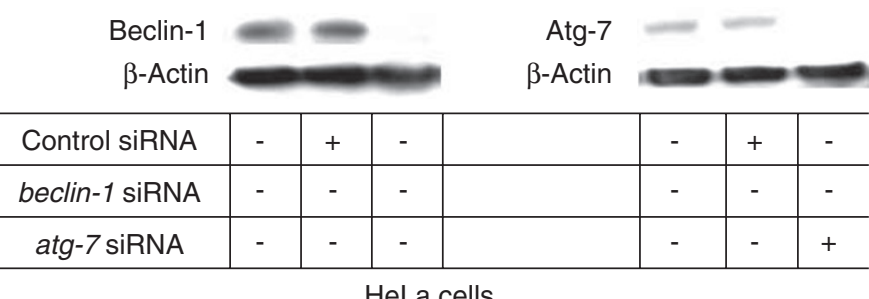

(ii)

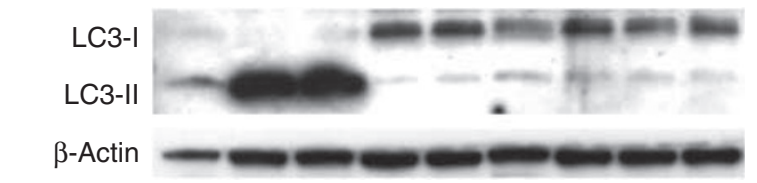

\begin{tabular}{c|c|c|c|c|c|c|c|c|c}
\hline No GP & - & + & - & - & + & - & - & + & - \\
\hline $\mathrm{No} A A$ & - & - & + & - & - & + & - & - & + \\
\hline $\mathrm{NH}_{4} \mathrm{Cl}$ & \multicolumn{3}{c|}{+} & \multicolumn{2}{|c}{+} & + \\
\hline siRNA & \multicolumn{1}{|c}{ Control } & \multicolumn{2}{|c}{ beclin-1 } & \multicolumn{2}{|c}{ atg-7 } \\
\hline Time (h) & \multicolumn{6}{c}{$48 \mathrm{~h}$} \\
\hline
\end{tabular}

HeLa cells

(ii)

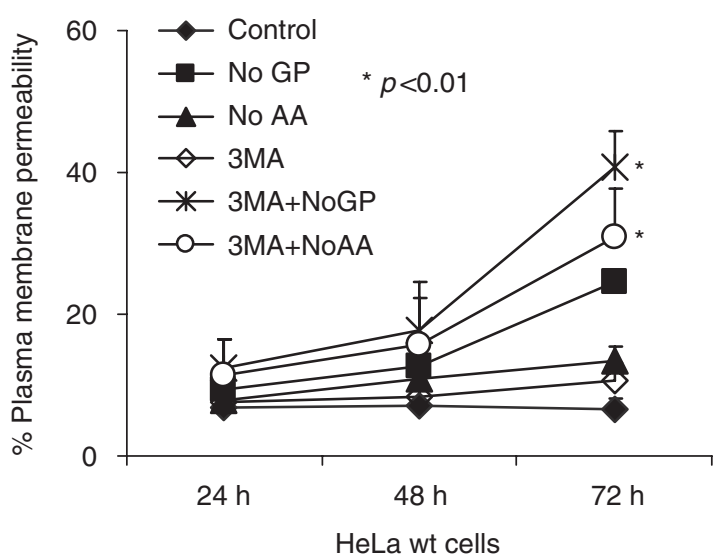

(iii)

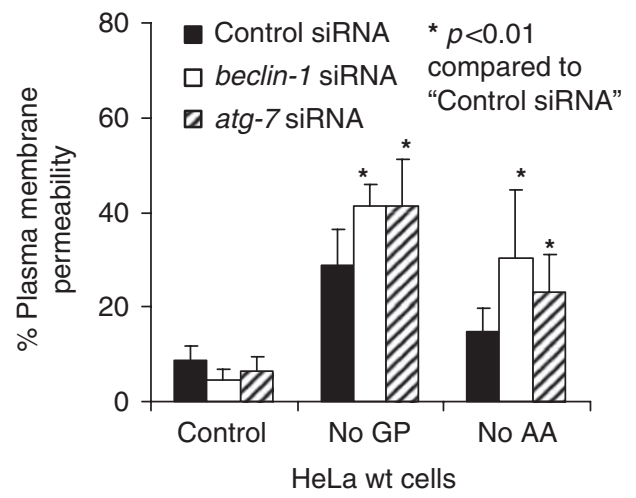

Figure 2 Continued

starvation-induced cell death in HeLa cells. Figure 2fi shows that GP starvation induced cell death up to $25 \%$ and AA starvation induced cell death only to $13 \%$ compared to $7 \%$ of cell death with non-starvation treatment after $72 \mathrm{~h}$. When autophagy inhibitor 3-MA was added, GP starvation-induced cell death was elevated to $40 \%$ and AA starvation-induced cell 
death was elevated to $30 \%$ (Figure 2fii). When another autophagy inhibitor wortmannin was added in HeLa cells, GP starvation-induced cell death was increased to $36 \%$ and $A A$ starvation-induced cell death was increased to $43 \%$ (Supplementary Figure S4bii). GP or AA starvation-induced cell death was also significantly enhanced at 24 and $48 \mathrm{~h}$ (Supplementary Figure S4bii). When the autophagy genes beclin-1 and atg-7 were knocked down by siRNA in HeLa cells (Figure 2ei), GP starvation-induced cell death was increased from 29 to $41 \%$ and $41 \%$, respectively, and $A A$ starvation-induced cell death was increased from 15 to $30 \%$ and $23 \%$, respectively (Figure 2fiii). This suggests that autophagy is a cell survival mechanism under GP and AA starvation conditions similar to other published results. ${ }^{1}$

Starvation-induced autophagy is mediated by $\mathrm{O}_{2}^{\bullet-}$. Because both GP and AA starvation induced autophagy and $\mathrm{O}_{2}^{\bullet-}$ production, and as $\mathrm{H}_{2} \mathrm{O}_{2}$ production was absent during GP starvation (Figure 1; Supplementary S1, and S2), we hypothesized that starvation-induced autophagy is specifically mediated by $\mathrm{O}_{2}^{\bullet-}$. The production of $\mathrm{O}_{2}^{\bullet-}$ and $\mathrm{H}_{2} \mathrm{O}_{2}$ is a chain reaction, where $\mathrm{O}_{2}^{\bullet-}$ is converted to $\mathrm{H}_{2} \mathrm{O}_{2}$ by SOD, and $\mathrm{H}_{2} \mathrm{O}_{2}$ can either be converted to $\mathrm{H}_{2} \mathrm{O}$ by other antioxidant enzymes (such as catalase, GPx, and PrxIII), or to ${ }^{\bullet} \mathrm{OH}$ by $\mathrm{Fe}^{2+}$ or $\mathrm{Cu}^{+}$. $^{3}$ Therefore, the levels of $\mathrm{O}_{2}^{\bullet-}$ and $\mathrm{H}_{2} \mathrm{O}_{2}$ can be adjusted by altering the antioxidant enzymes mentioned above. To determine the relative functions of $\mathrm{O}_{2}^{\bullet-}$ and $\mathrm{H}_{2} \mathrm{O}_{2}$ in the regulation of starvation-induced autophagy, we manipulated the cellular levels of these two ROS species by modifying the level of SOD2 through overexpression and siRNA knockdown or by treating cells with exogenous catalase. In Figure 3, ROS generation and autophagy was determined in wild-type (wt) HeLa cells or HeLa cells with stable overexpression of SOD2 (SOD2) in the mitochondria (Figure 3a; Supplementary Figure S5). Because SOD2 catalyzes the conversion of $\mathrm{O}_{2}^{\bullet-}$ to $\mathrm{H}_{2} \mathrm{O}_{2}$, we expected SOD2 cells to exhibit decreased $\mathrm{O}_{2}^{\bullet-}$ levels and increased $\mathrm{H}_{2} \mathrm{O}_{2}$ levels. Compared to levels in the wt cells, both GP starvation-induced autophagy and $\mathrm{O}_{2}^{\bullet-}$ levels in SOD2 cells were significantly decreased. In addition, the percentage of cells with AVOs and GFP-LC3 puncta decreased from 22 to $1 \%$ and from 32 to $13 \%$, respectively, whereas $\mathrm{O}_{2}^{\bullet-}$ generation was reduced from 30 to $8 \%$ in SOD2 cells (Figure 3b). As expected, GP starvation-induced $\mathrm{H}_{2} \mathrm{O}_{2}$ generation was significantly increased by SOD2 overexpression, from 7 to $20 \%$ (Figure 3b). Similarly, AA starvation-induced autophagy and $\mathrm{O}_{2}^{\circ-}$ generation were significantly decreased in SOD2 cells compared with that in wt cells. The percentage of cells with AVOs and GFP-LC3 puncta decreased significantly from 18 to $1 \%$ and from 38 to $13 \%$, respectively, whereas $\mathrm{O}_{2}^{\bullet-}$ generation was decreased from 33 to $4 \%$ in SOD2 cells (Figure $3 c$ ). AA starvation-induced $\mathrm{H}_{2} \mathrm{O}_{2}$ levels were $32 \%$ in both wt and SOD2 cells (Figure $3 \mathrm{c}$ ). GP and AA starvation-induced LC3-II protein levels were also decreased in SOD2 cells compared to that in wt cells (Figure 3d). Because the inhibition of autophagy by 3-MA, wortmannin, and siRNAs against beclin-1 and atg-7 increased GP and AA starvation-induced cell death (Figures 2f; Supplementary Figure S4bii), it is expected that SOD2 overexpression would also elevate GP and AA starvation- induced cell death. This is demonstrated in Figure $3 e$. In the wt HeLa cells, starvation of GP or AA did not significantly increase cell death compared to control whereas in SOD2 HeLa cells, GP starvation increased cell death from 13 to $45 \%$. Similarly, AA starvation increased cell death from 11 to $29 \%$ compared to that in wt cells at $48 \mathrm{~h}$. After $72 \mathrm{~h}$, SOD2 overexpression in cells increased GP starvation-induced cell death from 25 to $62 \%$ and increased AA starvation-induced cell death from 13 to $50 \%$ (Figure 3e). When autophagy inhibitors 3-MA (Figure 3f) and wortmannin (Supplementary Figure S4biii) were added, cell death induced by GP or AA starvation in SOD2 HeLa cells was not significantly affected. This indicates that when GP and AA starvation-induced autophagy was reduced to a very low level by $\mathrm{O}_{2}^{\bullet-}$ scavenger SOD2 (Figure $3 b, c$, and d), addition of other autophagy inhibitors (3-MA, wortmannin) would not further increase the levels of cell death induced by GP or AA starvation.

Next, we used siRNA to knock down the expression of SOD2 in HeLa cells (Figure 4a). SOD2 knockdown increased starvation-induced $\mathrm{O}_{2}^{\circ-}$ levels from 60 to $80 \%$ (GP starvation) and from 40 to $74 \%$ (AA starvation) compared to cells transfected with control siRNA (Figure $4 \mathrm{~b}$ ). In addition, SOD2 knockdown significantly decreased AA starvation-induced $\mathrm{H}_{2} \mathrm{O}_{2}$ levels from 24 to $12 \%$ whereas GP starvation-induced $\mathrm{H}_{2} \mathrm{O}_{2}$ was not affected (Figure $4 \mathrm{~b}$ ), because no significant induction was observed (Figures 1a and 4b). Along with increased $\mathrm{O}_{2}^{\bullet-}$ levels, SOD2 knockdown cells had higher levels of GP and AA starvation-induced autophagy: the percentage of cells with AVOs was increased from 31 to $50 \%$ and from 23 to $38 \%$, respectively, whereas the percentage of cells with GFP-LC3 puncta was increased from 40 to $54 \%$ and from 34 to $55 \%$, respectively (Figure 4b). LC3-II protein levels following GP and AA starvation were also significantly increased by SOD2 knockdown (Figure 4c). Thus, SOD2 knockdown cells had increased $\mathrm{O}_{2}^{\bullet-}$ (with decreased or unchanged $\mathrm{H}_{2} \mathrm{O}_{2}$ ), and increased starvationinduced autophagy. In contrast to SOD2 overexpression (Figure 3e), SOD2 knockdown decreased GP starvationinduced cell death from 29 to $16 \%$ and $A A$ starvation-induced cell death from 15 to $7 \%$ at $72 \mathrm{~h}$ (Figure $4 \mathrm{~d}$ ). This indicates that when starvation-induced autophagy is enhanced by SOD2 knockdown, starvation-induced cell death would be reduced, agreeing with the cell survival mechanism of autophagy under starvation conditions. Taken together, these data show that $\mathrm{O}_{2}^{\bullet-}$ levels regulated by SOD2 are strongly correlated with starvation-induced autophagy.

Others have shown that exogenous catalase enzyme can be added to cells extracellularly to scavenge intracellularly produced $\mathrm{H}_{2} \mathrm{O}_{2}{ }^{8,15,22,27}$ Because cellular $\mathrm{H}_{2} \mathrm{O}_{2}$ is generated by a chain reaction from $\mathrm{O}_{2}^{\circ-}$, catalase can also indirectly reduce cellular $\mathrm{O}_{2}^{\bullet-}$ levels. ${ }^{3}$ The three major cellular $\mathrm{ROS}$ species, $\mathrm{O}_{2}^{\bullet-}, \mathrm{H}_{2} \mathrm{O}_{2}$, and ${ }^{\bullet} \mathrm{OH}$, are in flux through a chain reaction. ${ }^{2,3} \mathrm{O}_{2}^{\bullet-}$ that is mainly produced from $\mathrm{mETC}$ complexes I and III will be catalyzed to $\mathrm{H}_{2} \mathrm{O}_{2}$ by SOD. Then $\mathrm{H}_{2} \mathrm{O}_{2}$ can either be converted to ${ }^{\circ} \mathrm{OH}$ by $\mathrm{Fe}^{2+}$ or $\mathrm{Cu}^{+}$or be catalyzed to $\mathrm{H}_{2} \mathrm{O}$ by catalase, GPx, and PrxllI. Therefore, we treated HeLa cells with catalase and compared autophagy, ROS induction, and cell death under control and starvation conditions (Figure 5). We found that starvation-induced $\mathrm{O}_{2}^{\bullet-}$ was reduced from 52 to $5 \%$ (GP starvation) or from 54 to $10 \%$ 


\section{a SOD2}

$\beta$-Actin

wt SOD2

HeLa cells b

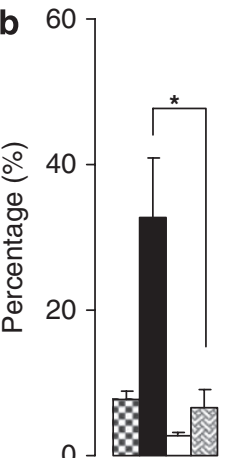

wt, control * $p<0.01$

wt, GP starvation

$\square$ SOD2, control

四 SOD2, GP starvation

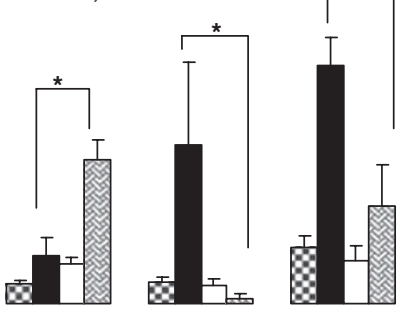

\begin{tabular}{c|c|c|c|c}
\hline Measurement & Ethidium & DCF & AVOs & GFP-LC3 \\
\hline Time & $48 \mathrm{~h}$ & $48 \mathrm{~h}$ & $72 \mathrm{~h}$ & $48 \mathrm{~h}$ \\
\hline
\end{tabular}

HeLa cells

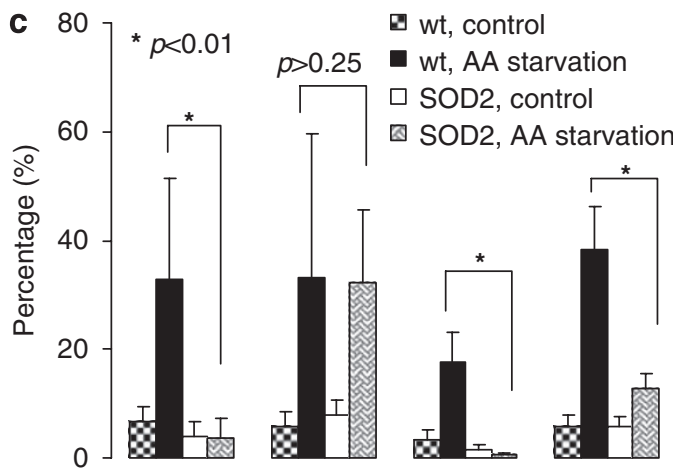

\begin{tabular}{c|c|c|c|c}
\hline Measurement & Ethidium & DCF & AVOs & GFP-LC3 \\
\hline Time & $48 \mathrm{~h}$ & $48 \mathrm{~h}$ & $72 \mathrm{~h}$ & $48 \mathrm{~h}$ \\
\hline
\end{tabular}

d LC3-I

LC3-II

$\beta$-Actin

\begin{tabular}{c|c|c|c|c|c|c}
\hline No GP & - & + & - & - & + & - \\
\hline No AA & - & - & + & - & - & + \\
\hline $\mathrm{NH}_{4} \mathrm{Cl}$ & \multicolumn{3}{|c|}{+} & \multicolumn{3}{|c}{+} \\
\hline HeLa & \multicolumn{3}{|c}{ wt } & \multicolumn{3}{|c}{ SOD2 } \\
\hline Time & \multicolumn{5}{c}{$48 \mathrm{~h}$} \\
\hline
\end{tabular}

HeLa cells
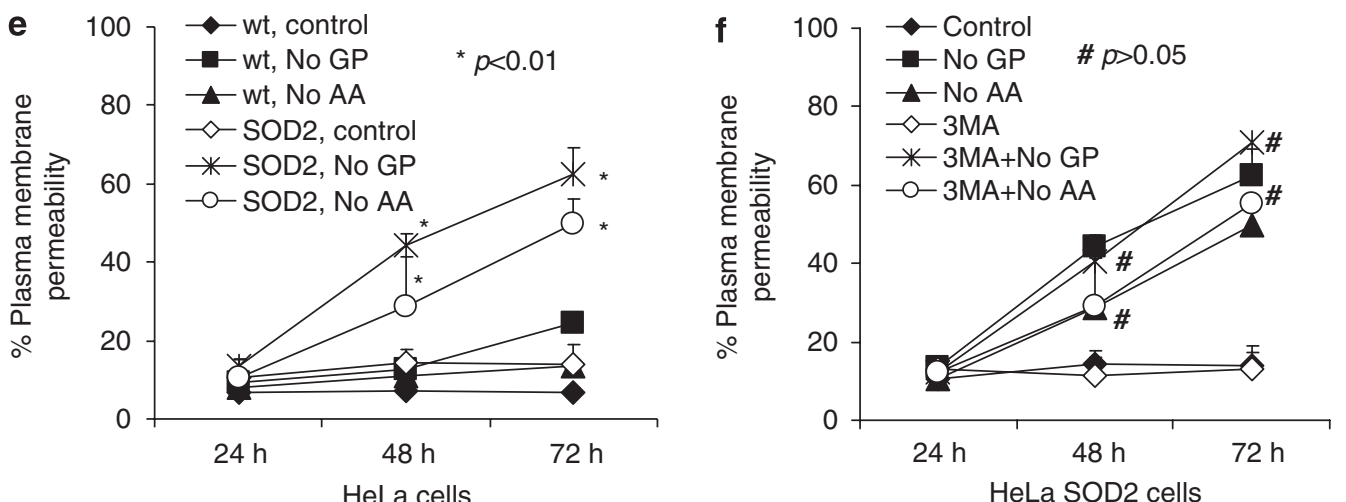

Figure 3 Overexpression of SOD2 downregulates autophagy but upregulates cell death induced by GP or AA starvation in HeLa cells. (a) Comparison of SOD2 expression between the wild-type (wt) and SOD2 overexpressing (SOD2) HeLa cells. $\beta$-Actin was used as a loading control. (b and $\mathbf{c}$ ) Effect of SOD2 overexpression on ROS generation, formation of AVOs, and GFP-LC3 dots (puncta) induced by GP and AA starvation, respectively. The percentages of ethidium fluorescence and DCF fluorescence represent the levels of intracellular $\mathrm{O}_{2}^{\bullet-}$ and $\mathrm{H}_{2} \mathrm{O}_{2}$, respectively, as described in Figure 1. (d) Effect of SOD2 overexpression on formation of LC3-II after cells were starved of $\mathrm{GP}$ or AA for $48 \mathrm{~h}$. $\beta$-Actin was used as a loading control. Cells were treated with the lysosomal inhibitor $\mathrm{NH}_{4} \mathrm{Cl}$ at $30 \mathrm{mM}$ for the determination of autophagy flux. (e) Effect of SOD2 overexpression on GP or AA starvation-induced cell death at 24,48 , and $72 \mathrm{~h}$. (f) Effect of 3-MA $(2 \mathrm{mM})$ on GP or AA starvation-induced cell death in SOD2 overexpression cells at 24,48 , and $72 \mathrm{~h}$. The percentage of plasma membrane permeability represents the percentage of cell death as described in Figure 2 . Error bars represent standard deviation (S.D.). All data are representative of three independent experiments

(AA starvation), whereas $\mathrm{H}_{2} \mathrm{O}_{2}$ was reduced from 43 to $9 \%$ (AA starvation) after catalase treatment (Figure $5 \mathrm{a}$ ). Although GP starvation did not significantly induce $\mathrm{H}_{2} \mathrm{O}_{2}$ production compared to control, the background level of $\mathrm{H}_{2} \mathrm{O}_{2}$ was reduced by catalase (Figure $5 \mathrm{a}$ ). In addition to decreased ROS levels, catalase-treated cells exhibited decreased 
a
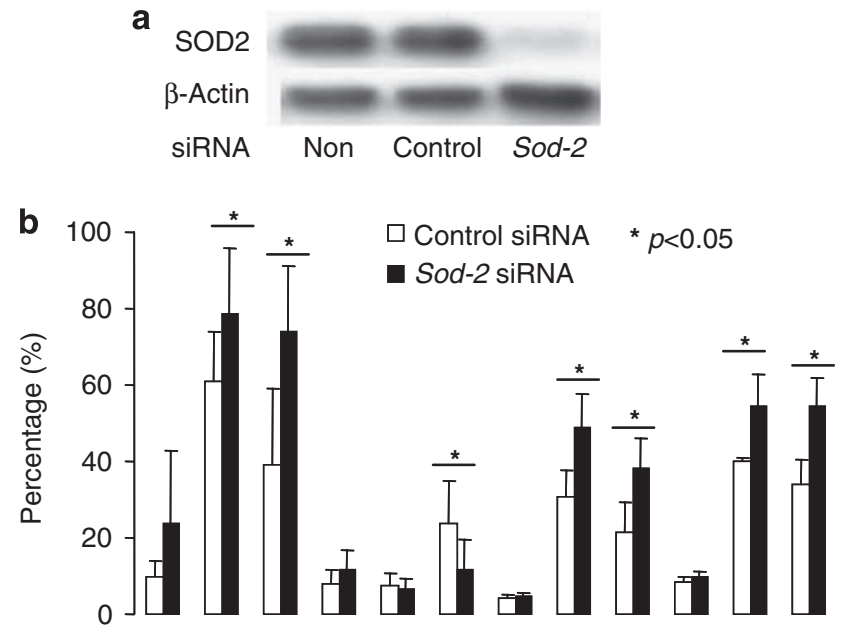

\begin{tabular}{c|c|c|c|c|c|c|c|c|c|c|c|c}
\hline No GP & - & + & - & - & + & - & - & + & - & - & + & - \\
\hline No AA & - & - & + & - & - & + & - & - & + & - & - & + \\
\hline Measurement & \multicolumn{2}{|c|}{ Ethidium } & \multicolumn{2}{|c}{ DCF } & \multicolumn{2}{|c}{ AVOs } & \multicolumn{2}{|c}{ GFP-LC3 } \\
\hline Time & \multicolumn{2}{|c|}{$48 \mathrm{~h}$} & \multicolumn{2}{|c|}{$48 \mathrm{~h}$} & \multicolumn{2}{|c}{$72 \mathrm{~h}$} & \multicolumn{2}{|c}{$48 \mathrm{~h}$} \\
\hline
\end{tabular}

HeLa cells

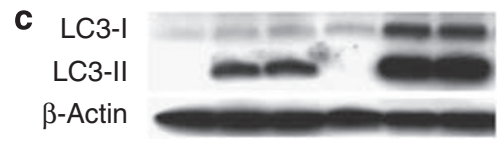

\begin{tabular}{c|c|c|c|c|c|c}
\hline No GP & - & + & - & - & + & - \\
\hline No AA & - & - & + & - & - & + \\
\hline $\mathrm{NH}_{4} \mathrm{Cl}$ & \multicolumn{3}{|c}{+} & \multicolumn{2}{|c}{+} \\
\hline siRNA & \multicolumn{3}{|c}{ Control } & Sod-2 \\
\hline Time & \multicolumn{5}{|c}{$48 \mathrm{~h}$} \\
\hline
\end{tabular}

HeLa cells

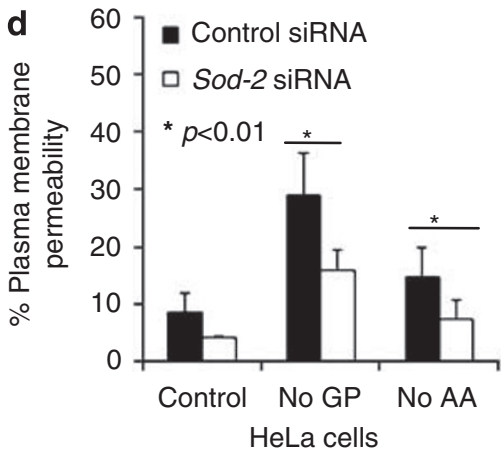

Figure 4 siRNA knockdown of sod-2 upregulates autophagy but downregulates cell death induced by GP or AA starvation in HeLa cells. (a) Western blot showing that SOD2 expression was reduced by sod-2 siRNA. $\beta$-Actin was used as a loading control. (b) Effect of sod-2 siRNA on ROS generation, formation of AVOs, and GFP-LC3 dots (puncta). The percentages of ethidium fluorescence and DCF fluorescence represent the levels of intracellular $\mathrm{O}_{2}^{\bullet-}$ and $\mathrm{H}_{2} \mathrm{O}_{2}$, respectively, as described in Figure 1. (c) Effect of sod-2 siRNA on formation of LC3-II. $\beta$-Actin was used as a loading control. Cells were treated with the lysosomal inhibitor $\mathrm{NH}_{4} \mathrm{Cl}$ at $30 \mathrm{mM}$ for the determination of autophagy flux. (d) Effect of sod-2 siRNA on cell death. The percentage of plasma membrane permeability represents the percentage of cell death as described in Figure 2. Error bars represent standard deviation (S.D.). All data are representative of three independent experiments

starvation-induced autophagy. The percentage of cells with AVOs was decreased from 31 to $1 \%$ (GP starvation) or from 18 to $1 \%$ (AA starvation), and the percentage of cells with GFP-LC3 puncta was decreased from 40 to $11 \%$ (GP starvation) or from 38 to $11 \%$ (AA starvation) after catalase treatment (Figure 5a). Starvation-induced LC3-II protein level was also significantly reduced by catalase (Figure $5 b$ ). Cell death induced by GP and AA starvation was increased from 25 to $60 \%$ and from 13 to $39 \%$, respectively, at $72 \mathrm{~h}$ of catalase treatment (Figure $5 \mathrm{c}$ ). When another ROS scavenger, $\mathrm{N}$-acetyl-cysteine (NAC) was used in HeLa cells, autophagy induced by GP or AA starvation was significantly reduced and cell death was increased (data not shown). Thus, catalase treatments lowered both $\mathrm{O}_{2}^{\bullet-}$ and $\mathrm{H}_{2} \mathrm{O}_{2}$ levels and reduced starvation-induced autophagy but increased starvation-induced cell death.
Autophagy induced by mETC inhibitors is mediated by $\mathbf{O}_{2}^{\bullet-}$. Besides starvation, many other stimuli are known to induce autophagy. ${ }^{1,2}$ We sought to determine whether $\mathrm{O}_{2}^{\bullet-}$ mediation of autophagy is specific to starvation conditions, or if it is regulating autophagy through other stimuli. Our previous studies indicate that $\mathrm{mETC}$ inhibitors (including complex I inhibitor rotenone, complex II inhibitor TTFA, and complex I/SOD inhibitor 2-ME ${ }^{23,28}$ ) can induce ROSmediated autophagy and autophagic cell death in cancer cells. ${ }^{17,18}$ In these studies, SOD2 overexpression reduced autophagy, supporting the involvement of $\mathrm{O}_{2}^{\bullet-}$ in autophagy induction. However, by measuring ROS only with dihydroethidium (DHE), which is reported to detect $\mathrm{O}_{2}^{\bullet-}$ specifically, ${ }^{27}$ we failed to directly address the function of $\mathrm{H}_{2} \mathrm{O}_{2}$. Therefore, in the present study we investigated the relative functions of $\mathrm{O}_{2}^{\bullet-}$ and $\mathrm{H}_{2} \mathrm{O}_{2}$ on autophagy induced by these 


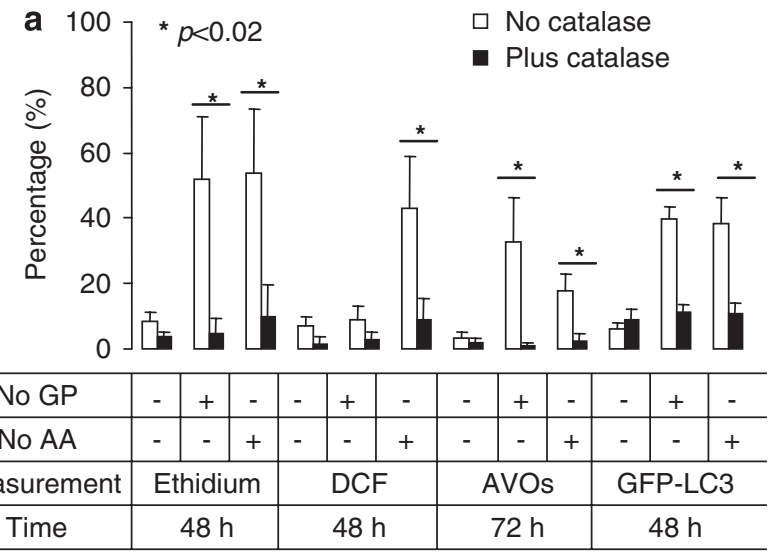

HeLa cells

b

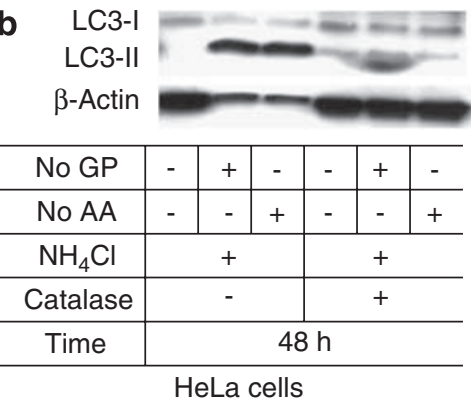

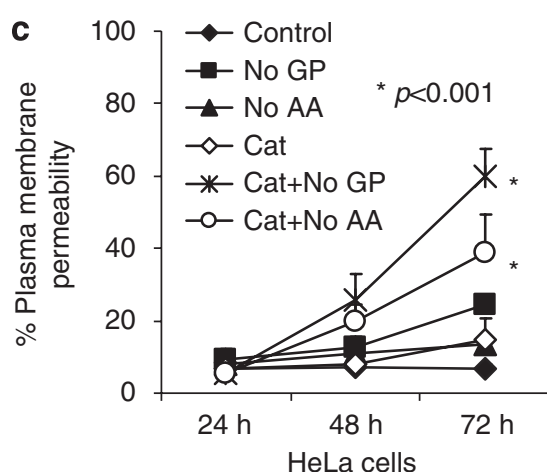

Figure 5 Catalase downregulates autophagy but upregulates cell death induced by GP or AA starvation in HeLa cells. (a) Effect of catalase (1000 U/ml) on ROS generation, formation of AVOs, and GFP-LC3 dots (puncta). The percentages of ethidium fluorescence and DCF fluorescence represent the levels of intracellular $\mathrm{O}_{2}^{\bullet-}$ and $\mathrm{H}_{2} \mathrm{O}_{2}$, respectively, as described in Figure 1. (b) Effect of catalase $(1000 \mathrm{U} / \mathrm{ml})$ on formation of $\mathrm{LC} 3-\mathrm{Il}$ at $48 \mathrm{~h}$. $\beta$-Actin was used as a loading control. Cells were treated with the lysosomal inhibitor $\mathrm{NH}_{4} \mathrm{Cl}$ at $30 \mathrm{mM}$ for the determination of autophagy flux. (c) Effect of catalase $(1000 \mathrm{U} / \mathrm{ml})$ on cell death at 24,48 , and $72 \mathrm{~h}$. The percentage of plasma membrane permeability represents the percentage of cell death as described in Figure 2. Error bars represent standard deviation (S.D.). All data are representative of three independent experiments

stimuli. Treatment with rotenone or TTFA causes increased production of $\mathrm{O}_{2}^{\bullet-}$, which can be converted to $\mathrm{H}_{2} \mathrm{O}_{2}$ by SOD. ${ }^{3,17}$ Because rotenone and TTFA can induce $\mathrm{O}_{2}^{\bullet-}$ production at as early as $0.5 \mathrm{~h}$, formation of GFP-LC3 puncta at $16 \mathrm{~h}$, AVOs formation and cell death at $24 \mathrm{~h},{ }^{17}$ we measured ROS at 6 and $24 \mathrm{~h}$, formation of GFP-LC3 puncta and AVOs at $24 \mathrm{~h}$, and cell death at $24 \mathrm{~h}$, in the present study. When combined with 2-ME, the levels of $\mathrm{O}_{2}^{\bullet-}$ induced by rotenone and TTFA were significantly increased from 46 to $57 \%$ and from 37 to $54 \%$, respectively, in HeLa cells at $24 \mathrm{~h}$ (Figure 6a). Accordingly, 2-ME reduced the levels of $\mathrm{H}_{2} \mathrm{O}_{2}$ production from 59 to $38 \%$ following rotenone treatment and from 39 to $25 \%$ following TTFA treatment, in HeLa cells at $24 \mathrm{~h}$ (Figure 6a). Similar results were also obtained when HeLa cells were treated for $6 \mathrm{~h}$ (Supplementary Figure S6). In correlation with the increase in $\mathrm{O}_{2}^{\circ-}$ levels, the percentage of cells with GFP-LC3 puncta induced by rotenone and TTFA was also increased from 20 to $39 \%$ and from 22 to $34 \%$, respectively, by the addition of 2-ME in HeLa cells at $24 \mathrm{~h}$ (Figure $6 \mathrm{~b}$ ). The protein level of LC3-II induced by rotenone or TTFA was also significantly increased with the addition of 2-ME (Figure 6c). Similar results were also obtained in HEK293 cells (Supplementary Figure S7). In HEK293 cells treated with rotenone or TTFA, the levels of $\mathrm{O}_{2}^{\bullet-}$ production and autophagy (formation of green fluorescent protein (GFP) puncta and LC3-II) were both increased by the addition of 2-ME. Notably, $\mathrm{H}_{2} \mathrm{O}_{2}$ production was not significantly induced by rotenone, TTFA or 2-ME, alone or in combination (Supplementary Figure S7). Taken together, these data suggest that similar to starvation, autophagy induced by mETC inhibitors is regulated by $\mathrm{O}_{2}^{\bullet-}$. In contrast to that starvation-induced autophagy reducing cell death, our previous study showed that rotenone-, TTFA-, or 2-ME-induced autophagy increases cell death. ${ }^{17,18}$ In this study, cell death induced by the combination of rotenone and 2-ME or TTFA and 2-ME was also investigated. Figure $6 \mathrm{~d}$ shows that cell death induced by rotenone and TTFA was increased from 20 to $30 \%$ and from 20 to $40 \%$, respectively, following addition of addition of 2-ME. In contrast, 2-ME alone induced cell death of $13 \%$ compared to cell death of $8 \%$ in control at $24 \mathrm{~h}$. Thus, different from that of starvationinduced autophagy, the enhancement of rotenone- or TTFAinduced autophagy (by 2-ME) leads to the enhancement of cell death.

Autophagy induced by exogenous $\mathrm{H}_{2} \mathrm{O}_{2}$ is mediated by $\mathrm{O}_{2}^{\bullet-}$. Exogenous $\mathrm{H}_{2} \mathrm{O}_{2}$ is another stimulus known to induce autophagy. ${ }^{7,9,12-16,21,29-31}$ In many previous in vitro studies, 
a

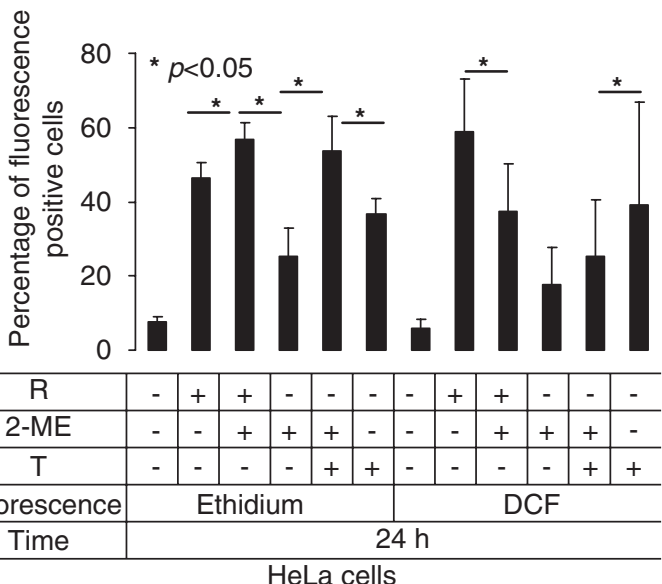

C

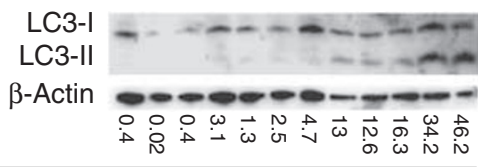

\begin{tabular}{|c|c|c|c|c|c|c|c|c|c|c|c|}
\hline $\mathrm{R}$ & & + & & & & & + & - & - & & - \\
\hline $\begin{array}{l}\mathrm{T} \\
\end{array}$ & - & - & + & -1. & & & & + & - & & + \\
\hline 2-ME & - & - & - & + & & & - & - & + & & + \\
\hline $\mathrm{NH}_{4} \mathrm{Cl}$ & & & - & & & & & & & & \\
\hline
\end{tabular}

HeLa cells

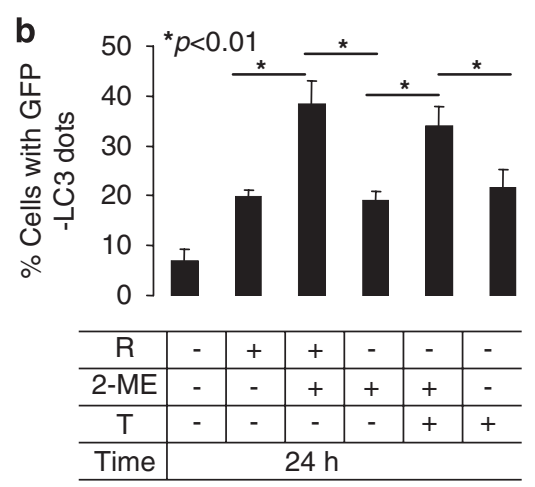

HeLa cells

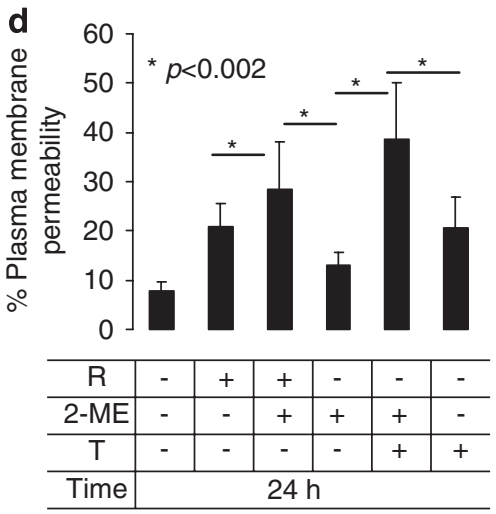

HeLa cells

Figure $6 \mathrm{SOD}$ inhibitor 2-ME upregulates autophagy and cell death induced by METC inhibitors rotenone and TTFA in HeLa cells. Cells were treated with 0.1 mM 2-ME and/or $50 \mu \mathrm{M}$ rotenone (R) and/or $0.5 \mathrm{mM}$ TTFA (T) for $24 \mathrm{~h}$. (a) ROS generation. The percentages of ethidium fluorescence and DCF fluorescence represent the levels of intracellular $\mathrm{O}_{2}^{\bullet-}$ and $\mathrm{H}_{2} \mathrm{O}_{2}$, respectively, as described in Figure 1. (b) Formation of GFP-LC3 dots (puncta). (c) Formation of LC3-II. $\beta$-Actin was used as a loading control. Cells were treated with the lysosomal inhibitor $\mathrm{NH}_{4} \mathrm{Cl}$ at $30 \mathrm{mM}$ for the determination of autophagy flux. Numerical values indicate protein quantification by densitometry using QuantityOne software (Bio-Rad), normalized to $\beta$-actin. (d) Cell death. The percentage of plasma membrane permeability represents the percentage of cell death as described in Figure 2. Error bars represent standard deviation (S.D.). All data are representative of three independent experiments

addition of $\mathrm{H}_{2} \mathrm{O}_{2}$ has been used to mimic the effects of intracellularly produced $\mathrm{H}_{2} \mathrm{O}_{2}$, without actually measuring intracellular $\mathrm{H}_{2} \mathrm{O}_{2}$ because of the assumption that $\mathrm{H}_{2} \mathrm{O}_{2}$ can freely diffuse through biological membranes. ${ }^{7,9,12-16,21,29-31}$ Indeed, our previous study showed that addition of exogenous $\mathrm{H}_{2} \mathrm{O}_{2}$ to HEK293, U87, and HeLa cells induced ROS production without directly measuring intracellular levels of $\mathrm{H}_{2} \mathrm{O}_{2} \cdot{ }^{18}$ In the current study, we investigated the functions of both intracellular $\mathrm{O}_{2}^{\bullet-}$ and $\mathrm{H}_{2} \mathrm{O}_{2}$ on autophagy induced by exogenous $\mathrm{H}_{2} \mathrm{O}_{2}$. We found that the addition of exogenous $\mathrm{H}_{2} \mathrm{O}_{2}$ induced the production of intracellular $\mathrm{O}_{2}^{\circ-}$ but failed to increase intracellular $\mathrm{H}_{2} \mathrm{O}_{2}$ in $\mathrm{HeLa}$ cells (Figure 7a). Similar results were obtained in HEK293 cells: exogenous $\mathrm{H}_{2} \mathrm{O}_{2}$ induced $\mathrm{O}_{2}^{*-}$ production (Supplementary Figure S8a), formation of LC3-II (Supplementary Figure S8b) but failed to increase the production of intracellular $\mathrm{H}_{2} \mathrm{O}_{2}$ (Supplementary data Figure S8a). When SOD2 was overexpressed in HeLa cells (Figure $3 \mathrm{a}$ ), $\mathrm{O}_{2}^{--}$production was greatly reduced from 77 to $10 \%$ whereas intracellular $\mathrm{H}_{2} \mathrm{O}_{2}$ production was significantly increased from 1 to $17 \%$ following treatment with exogenous $\mathrm{H}_{2} \mathrm{O}_{2}$ (Figure 7a). Along with decreasing intracellular $\mathrm{O}_{2}^{--}$levels, SOD2 over- expression significantly decreased the percentage of cells with AVOs from 21 to $4 \%$ (Figure 7a) and the LC3-II protein level (Figure $7 \mathrm{~b}$ ) following exogenous $\mathrm{H}_{2} \mathrm{O}_{2}$ treatment. These results implicate $\mathrm{O}_{2}^{\circ-}$ in regulating exogenous $\mathrm{H}_{2} \mathrm{O}_{2}$-induced autophagy.

Superoxide $\left(\mathrm{O}_{2}^{\circ-}\right)$ production occurs upstream of PI3K class III and beclin-1 activation during starvationinduced autophagy. Scherz-Shouval et al. ${ }^{15}$ showed that partial $\mathrm{H}_{2} \mathrm{O}_{2}$ was produced from downstream of PI3K class III-beclin-1 complex activation during AA starvation-induced autophagy. ${ }^{15}$ In this study, we found that GP or AA starvation-induced $\mathrm{H}_{2} \mathrm{O}_{2}$ generation was increased by 3-MA (Figure 8a), whereas starvation-induced autophagy was decreased by 3-MA (Figure 2d; Supplementary Figure S4a), in HeLa cells. 3-MA treatment had no effect on $\mathrm{O}_{2}^{--}$ levels in HeLa cells (Figure 8a). When another autophagy inhibitor wortmannin (Supplementary Figure S4bi) was used in HeLa cells, the levels of both $\mathrm{O}_{2}^{--}$and $\mathrm{H}_{2} \mathrm{O}_{2}$ induced by GP or AA starvation were not significantly affected (Figure 8b). In addition, beclin-1 and atg-7 siRNAs knockdown failed to significantly affect GP or AA starvation- 
induced $\mathrm{O}_{2}^{\bullet-}$ and $\mathrm{H}_{2} \mathrm{O}_{2}$ production in HeLa cells (Figure $8 \mathrm{c}$ ). Thus, our results indicate that increased levels of $\mathrm{O}_{2}^{*-}$ following starvation occur upstream of PI3K class III-beclin-1 complex activation.

\section{Discussion}

Autophagy has been intensively studied in recent years. However, the mechanism of autophagy induction remains unclear. The involvement of ROS in autophagy has been

a

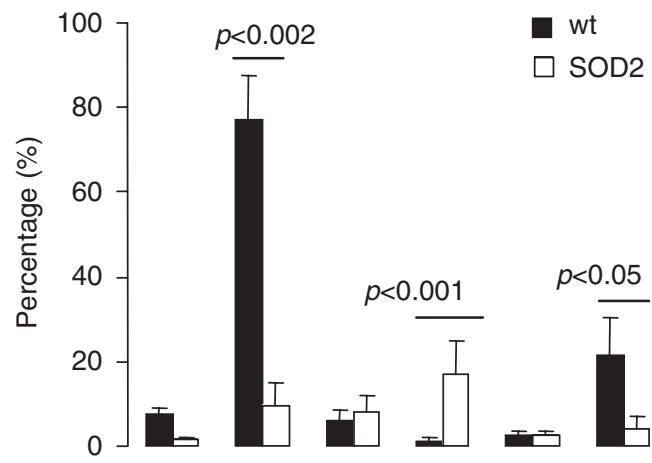

\begin{tabular}{c|c|c|c|c|c|c}
\hline $\mathrm{H}_{2} \mathrm{O}_{2}$ added & - & + & - & + & - & + \\
\hline Measurement & Ethidium & \multicolumn{2}{|c}{ DCF } & \multicolumn{2}{|c}{ AVOs } \\
\hline Time & \multicolumn{6}{|c}{$24 \mathrm{~h}$}
\end{tabular}

HeLa cells

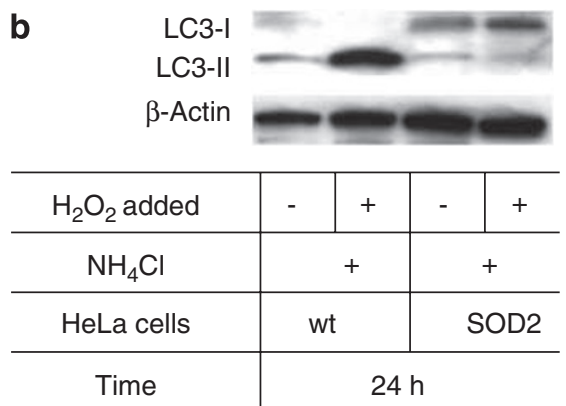

Figure 7 Overexpression of SOD2 downregulates autophagy induced by exogenous $\mathrm{H}_{2} \mathrm{O}_{2}$ in HeLa cells. Cells were treated with $1 \mathrm{mM} \mathrm{H}_{2} \mathrm{O}_{2}$ for $24 \mathrm{~h}$. (a) Effect of SOD2 overexpression on ROS generation and AVOs formation. The percentages of ethidium fluorescence and DCF fluorescence represent the levels of intracellular $\mathrm{O}_{2}^{\bullet-}$ and $\mathrm{H}_{2} \mathrm{O}_{2}$, respectively, as described previously. (b) Effect of SOD2 overexpression on LC3-II formation. $\beta$-Actin was used as a loading control. Cells were treated with the lysosomal inhibitor $\mathrm{NH}_{4} \mathrm{Cl}$ at $30 \mathrm{mM}$ for the determination of autophagy flux. Error bars represent standard deviation (S.D.). All data are representative of three independent experiments

Figure 8 Effects of autophagy inhibitors on ROS generation induced by GP or AA starvation in HeLa cells. (a) Effect of 3-MA $(2 \mathrm{mM})$ at $48 \mathrm{~h}$. (b) Effect of wortmannin (Wort, $0.2 \mu \mathrm{M}$ ) at $48 \mathrm{~h}$. (c) Effect of beclin-1 and atg-7 siRNAs at $48 \mathrm{~h}$. The percentages of ethidium fluorescence and DCF fluorescence represent the levels of intracellular $\mathrm{O}_{2}^{\bullet-}$ and $\mathrm{H}_{2} \mathrm{O}_{2}$, respectively, as described in Figure 1. Error bars represent standard deviation (S.D.) from three independent experiments a

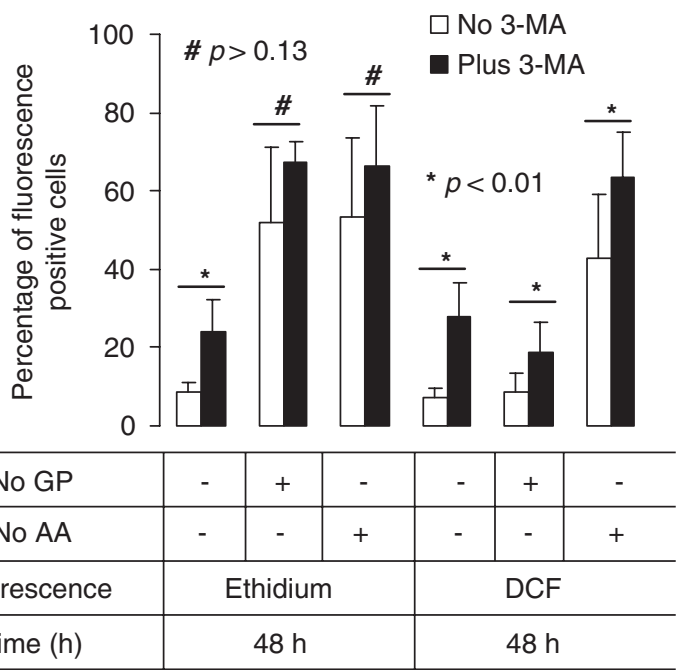

HeLa cells

b

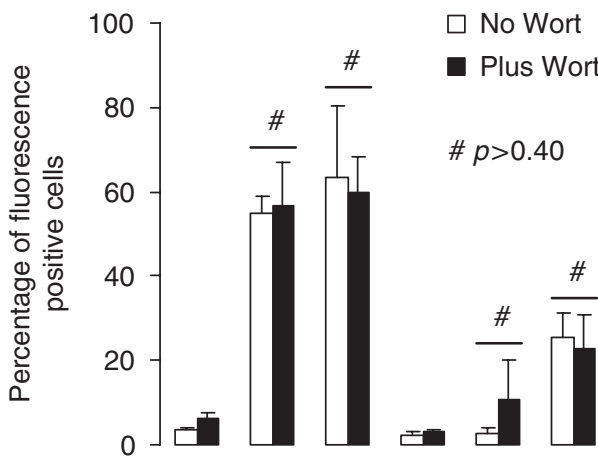

\begin{tabular}{c|c|c|c|c|c|c}
\hline No GP & - & + & - & - & + & - \\
\hline No AA & - & - & + & - & - & + \\
\hline Fluorescence & \multicolumn{2}{|c|}{ Ethidium } & \multicolumn{3}{|c}{ DCF } \\
\hline Time (h) & \multicolumn{2}{|c|}{$48 \mathrm{~h}$} & \multicolumn{2}{|c}{$48 \mathrm{~h}$}
\end{tabular}

HeLa cells
C

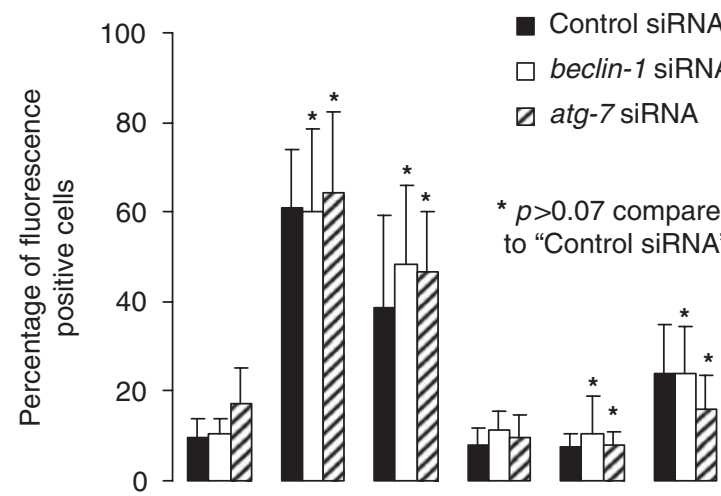

\begin{tabular}{c|c|c|c|c|c|c}
\hline No GP & - & + & - & - & + & - \\
\hline No AA & - & - & + & - & - & + \\
\hline Fluorescence & \multicolumn{6}{|c}{ Ethidium } \\
\hline \multicolumn{6}{c}{$48 \mathrm{~h}$} \\
\hline Time (h) & \multicolumn{6}{|c}{ DCF } \\
\hline
\end{tabular}

HeLa cells 
demonstrated in many studies, ${ }^{5-22}$ but the relative functions of $\mathrm{O}_{2}^{\bullet-}$ and $\mathrm{H}_{2} \mathrm{O}_{2}$ are not well established. In this study, we have compared the relative functions of $\mathrm{O}_{2}^{\bullet-}$ and $\mathrm{H}_{2} \mathrm{O}_{2}$ in the regulation of autophagy induced by $A A$ and GP starvation conditions, mETC inhibitors, and exogenous $\mathrm{H}_{2} \mathrm{O}_{2}$. Our findings indicate for the first time that autophagy is selectively mediated by $\mathrm{O}_{2}^{\bullet-}$, and that exogenous $\mathrm{H}_{2} \mathrm{O}_{2}$ is effectively converted to intracellular $\mathrm{O}_{2}^{\bullet-}$ leading to induction of autophagy.

Reactive oxygen species are regulated by a series of antioxidant enzymes. Because SOD is the antioxidant enzyme to convert $\mathrm{O}_{2}^{\bullet-}$ to $\mathrm{H}_{2} \mathrm{O}_{2},{ }^{2,3}$ the level of $\mathrm{O}_{2}^{\bullet-}$ can be controlled by modulating SOD activity. The findings from this study indicate that upregulation of autophagy can be achieved by inhibiting SOD to elevate $\mathrm{O}_{2}^{\circ-}$ levels, and that activating SOD can downregulate autophagy. Activation of downstream antioxidant enzymes that catalyze $\mathrm{H}_{2} \mathrm{O}_{2}$ to $\mathrm{H}_{2} \mathrm{O}$ such as catalase, GPx, and PrxIII can also reduce autophagy levels. ${ }^{2}$ However by reducing $\mathrm{H}_{2} \mathrm{O}_{2}$ level, the levels of $\mathrm{O}_{2}^{--}$are also reduced through a chain reaction., ${ }^{2,3}$ This illustrates the importance for measuring all forms of ROS.

One interesting phenomenon observed from this study is that two different starvation conditions (GP and AA starvation) induce different spectra of ROS production in a same type of cells. GP starvation induces $\mathrm{O}_{2}^{\bullet-}$ production but not $\mathrm{H}_{2} \mathrm{O}_{2}$, whereas AA starvation induces both $\mathrm{O}_{2}^{\bullet-}$ and $\mathrm{H}_{2} \mathrm{O}_{2}$ production. Because both starvation conditions induce autophagy, it should be expected that $\mathrm{O}_{2}^{--}$is the ROS-mediating autophagy. However, the AA starvation system is widely used for autophagy studies, and both $\mathrm{O}_{2}^{\bullet-}$ and $\mathrm{H}_{2} \mathrm{O}_{2}$ are simultaneously produced in this type of starvation. ${ }^{15}$ There are several possible reasons why $\mathrm{H}_{2} \mathrm{O}_{2}$ is the more commonly investigated ROS, whereas the function of $\mathrm{O}_{2}^{\bullet-}$ has been neglected under AA starvation. First, because $\mathrm{O}_{2}^{\circ-}$ and $\mathrm{H}_{2} \mathrm{O}_{2}$ are simultaneously produced under AA starvation, they could have redundant function in autophagy regulation. Second, $\mathrm{H}_{2} \mathrm{O}_{2}$ is more stable than $\mathrm{O}_{2}^{\cdot-}$ and is found to be a signaling molecule in many biological pathways. Third, $\mathrm{H}_{2} \mathrm{O}_{2}$ scavengers such as catalase and NAC are readily available. ${ }^{3}$ Fourth, many studies use exogenous $\mathrm{H}_{2} \mathrm{O}_{2}$ as a control to mimic the effect of intracellularly produced $\mathrm{H}_{2} \mathrm{O}_{2}$. We show, however, that it is not possible to specify whether $\mathrm{O}_{2}^{\bullet-}$ or $\mathrm{H}_{2} \mathrm{O}_{2}$ is the mediator of AA starvation-induced autophagy simply based on the effect of $\mathrm{H}_{2} \mathrm{O}_{2}$ scavengers or the addition of exogenous $\mathrm{H}_{2} \mathrm{O}_{2} . \mathrm{H}_{2} \mathrm{O}_{2}$ scavengers such as catalase and NAC also effectively scavenge $\mathrm{O}_{2}^{\bullet-}$ because $\mathrm{O}_{2}^{\bullet-}$ can be quickly converted to $\mathrm{H}_{2} \mathrm{O}_{2}$ by SOD in the cell, and exogenous $\mathrm{H}_{2} \mathrm{O}_{2}$ can effect on the cells to produce $\mathrm{O}_{2}^{\bullet-}$ possibly by damaging mETC.

One interesting question is the source of ROS induced by starvation. Scherz-Shouval et al. ${ }^{15}$ demonstrated that significant amount of $A A$ starvation-induced $\mathrm{H}_{2} \mathrm{O}_{2}$ is located in mitochondria. Our results showed that overexpression or knockdown (by siRNA) of the mitochondria-localized SOD2 decreased or increased starvation-induced $\mathrm{O}_{2}^{\bullet-}$ also indirectly indicate that mitochondria are an important source of starvation-induced ROS. The localization of starvationinduced ROS will be the focus for future studies.

Some discrepancies exist on the time of ROS production and autophagy induced by AA starvation between this study and other studies from the literature. For example, several groups have shown that ROS and autophagy can be detected at earlier times (between 2 and $4 \mathrm{~h}$ ) whereas this study showed that ROS and autophagy can only be detected after $6 \mathrm{~h}$. This could be due to the variations of cell lines used, the relative health of the cells before starvation, and/or differences in detailed experimental procedures from different laboratories. Because earlier studies did not quantify both ROS species, $\mathrm{O}_{2}^{--}$and $\mathrm{H}_{2} \mathrm{O}_{2}$, simultaneously, but emphasized on $\mathrm{H}_{2} \mathrm{O}_{2}$ quantification, it is quite possible that these difference could also be due to the type of ROS detected. Nevertheless, the correlation between ROS production and induction of autophagy remains consistent in these studies.

Starvation-induced autophagy is associated with cell survival whereas autophagy induced by various other stimuli (including dopamine ${ }^{8}$ sodium selenite, ${ }^{13}$ mETC inhibitors rotenone and TFFA, ${ }^{17}$ SOD2 inhibitor $2-\mathrm{ME},{ }^{18}$ and exogenous $\mathrm{H}_{2} \mathrm{O}_{2}{ }^{12,18}$ ) is associated with cell death. We and others have found that these inducers of autophagy require ROS production. $^{8,13,12,18}$ Indeed, we have previously found that rotenone and TTFA induce $\mathrm{O}_{2}^{\bullet-}$ production and that overexpressing SOD2 blocks autophagy. ${ }^{17}$ This was reversed by knocking down SOD2 by siRNA. The data in the current study showed that combining the SOD2 inhibitor 2-ME with an mETC inhibitor increased $\mathrm{O}_{2}^{\bullet-}$ production, autophagy, and cell death. 2-ME is currently in clinical trials for treating cancers and might potentiate cell death through increased $\mathrm{O}_{2}^{\bullet-}$ production and induction of autophagy. Alternatively, increasing $\mathrm{O}_{2}^{\bullet-}$ production by using sod-2 siRNA could lead to cell survival under starvation conditions. In contrast, decreasing $\mathrm{O}_{2}^{\bullet-}$ production by SOD2 overexpression, catalase, or NAC reduced autophagy but increased cell death under starvation conditions. Therefore, autophagy can lead to cell survival and cell death under different stimuli even in a same type of cells. The complete mechanisms regulating autophagy-induced cell survival and cell death remain to be determined.

Exogenous $\mathrm{H}_{2} \mathrm{O}_{2}$ is frequently used to mimic the effect of intracellularly produced $\mathrm{H}_{2} \mathrm{O}_{2}$ and has been shown to induce autophagy. ${ }^{7,9,12-16,21}$ However, in these studies, the intracellular levels of $\mathrm{O}_{2}^{\bullet-}$ and $\mathrm{H}_{2} \mathrm{O}_{2}$ induced by exogenous $\mathrm{H}_{2} \mathrm{O}_{2}$ were not directly measured. We found that exogenous $\mathrm{H}_{2} \mathrm{O}_{2}$ increases the generation of intracellular $\mathrm{O}_{2}^{\bullet-}$ but failed to change levels of intracellular $\mathrm{H}_{2} \mathrm{O}_{2}$ (Figure 7; Supplementary Figure S8). These findings indicate that exogenous $\mathrm{H}_{2} \mathrm{O}_{2}$ induces autophagy through the generation of intracellular $\mathrm{O}_{2}^{\bullet-}$ (Figure 7; Supplementary Figure S8; Chen et al. ${ }^{18}$ ). This emphasizes the importance for determining the relative levels of $\mathrm{O}_{2}^{\bullet-}$ and $\mathrm{H}_{2} \mathrm{O}_{2}$.

Reactive oxygen species induces multiple downstream signals. We showed that $\mathrm{O}_{2}^{\bullet-}$ production occurs upstream of the activation of beclin-1 and PI3K class III and leads to induction of autophagy. In contrast, others have shown that blockage of PI3K class III activation with 3-MA or wortmannin prevents $\mathrm{H}_{2} \mathrm{O}_{2}$ production following $A A$ starvation. ${ }^{15}$ This could be due to cell-type-specific differences or the lack of determination of the relative amounts of $\mathrm{O}_{2}^{\bullet-}$ and $\mathrm{H}_{2} \mathrm{O}_{2}$ produced by AA starvation. Nevertheless, ROS could act further downstream by oxidizing Atg-4 and/or increasing beclin-1 expression leading to induction of autophagy. ${ }^{15,18}$ 


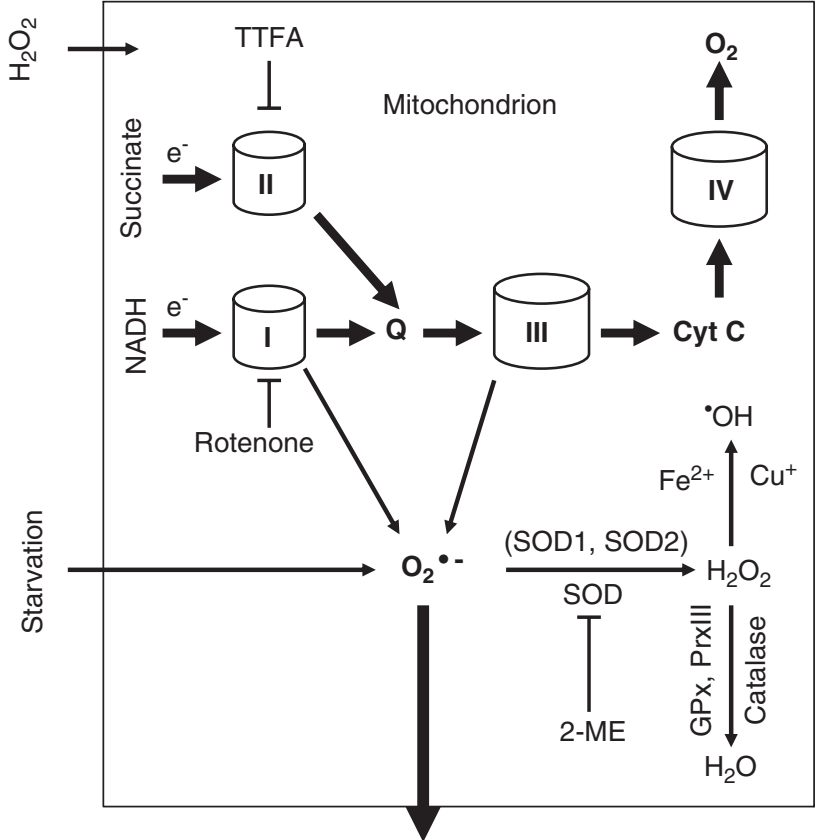

Autophagy

Figure 9 Model of autophagy induction mediated by superoxide $\left(\mathrm{O}_{2}^{\bullet-}\right)$. Autophagy can be induced by various stimuli such as starvation, $\mathrm{mETC}$ inhibitors rotenone and TTFA, the SOD inhibitor 2-ME, and exogenous $\mathrm{H}_{2} \mathrm{O}_{2}$. I, II, III, and IV represent mETC complexes I, II, III, and IV, respectively. 2-ME, 2-methoxyestradiol; Cyt C, cytochrome $c$; Q, ubiquinone-ubiquinol pool; GPx, glutathione peroxidase; PrxllI, peroxiredoxin III; SOD, superoxide dismutase; SOD1, Cu, Zn-SOD; SOD2, $\mathrm{Mn}-\mathrm{SOD}$. Arrows represent activation. Bars represent inhibition. Catalase can be found in cytoplasm and mitochondria ${ }^{33}$

However, exact downstream signaling events regulated by $\mathrm{O}_{2}^{\bullet-}$ leading to autophagy are unknown and will be the focus for future investigations.

Although we cannot exclude the possibility that $\mathrm{H}_{2} \mathrm{O}_{2}$ may be involved in autophagy regulation in other types of cells and with other stimuli, we propose a model for autophagy induction mediated by $\mathrm{O}_{2}^{--}$as shown in Figure 9. In our model, starvation, addition of exogenous $\mathrm{H}_{2} \mathrm{O}_{2}$, inhibition of SOD, or blockade of the electron transport chain causes increased $\mathrm{O}_{2}^{\bullet-}$ leading to autophagy. Because autophagy is involved in many human pathologies, ${ }^{32}$ our studies of autophagy regulation could provide insights for the development of novel drugs or approaches for controlling autophagy through $\mathrm{O}_{2}^{\bullet-}$ regulation in human diseases.

\section{Materials and Methods}

Reagents. Acridine orange, 3-MA, wortmannin, $\mathrm{H}_{2} \mathrm{O}_{2}$, 2-ME, rotenone, TTFA, DAPI (4',6-diamidino-2-phenylindole), catalase, and medium for GP (glucose, L-glutamine, sodium pyruvate, phenol red, $\mathrm{NaHCO}_{3}$, and serum) starvation were purchased from Sigma-Aldrich (Oakville, Ontario, Canada). Medium for AA (amino acids and serum) starvation (EBSS) was purchased from HyClone Laboratories Inc. (Logan, UT, USA). Dihydroethidium (DHE) and 5-(and-6)chloromethyl-2', 7'-dichlorodihydrofluorescein diacetate acetyl ester (CMH2DCFDA) were from Invitrogen (Burlington, Ontario, Canada). DHE, 2-ME, rotenone, TTFA, and DAPI were dissolved in dimethyl sulfoxide (DMSO). Catalase, 3-MA, and $\mathrm{H}_{2} \mathrm{O}_{2}$ were dissolved in double-distilled water. The final concentration of DMSO in media was less than $0.1 \%$ and it did not have any effect on the activities tested in this study (data of DMSO effect are not shown in this study). The concentrations of reagents used in this study were: $\mathrm{H}_{2} \mathrm{O}_{2}, 1.0 \mathrm{mM}$; 2-ME, $\quad 0.1 \mathrm{mM}$; 3-MA, $2.0 \mathrm{mM}$; wortmannin, $0.2 \mu \mathrm{M} ; \quad \mathrm{DHE}, \quad 3.2 \mu \mathrm{M}$; CM-H2DCFDA, $5 \mu \mathrm{M}$; rotenone, $50 \mu \mathrm{M}$; TTFA, $0.5 \mathrm{mM}$; and DAPI, $3.0 \mu \mathrm{M}$.

Antibodies and siRNAs. Beclin-1 primary antibody and its secondary antibody donkey anti-goat HRP were purchased from Santa Cruz Biotechnology Inc. (Santa Cruz, CA, USA). ATG-7 antibody was purchased from PromoKine Inc. (Germany). SOD2 antibody was purchased from StressGen Biotechnologies (Victoria, Canada). Rabbit anti-actin antibody was purchased from Sigma, rabbit anti-LC3 antibody from Abgent Inc. and their secondary antibody goat anti-rabbit $\lg \mathrm{G}(\mathrm{H}+\mathrm{L}) \mathrm{HRP}$ from Bio-Rad Laboratories. anti-LC3 mouse monoclonal antibody was purchased from NanoTools and its goat anti-mouse $\lg G(H+L)$ HRP from Bio-Rad Laboratories. The siRNAs specific for human beclin-1, atg-7, and sod-2 are same as in our previous study. ${ }^{18}$

Cell culture. Human embryonic kidney cell line HEK293, human glioma cancer cell line U87, and human cervical cancer cell line HeLa were maintained in a humidified $5 \% \mathrm{CO}_{2}, 37^{\circ} \mathrm{C}$ incubator in Dulbecco's modified Eagle's medium supplemented with $100 \mathrm{U} / \mathrm{ml}$ penicillin, $100 \mu \mathrm{g} / \mathrm{ml}$ streptomycin (Invitrogen). Media used for HEK293 and HeLa were supplemented with 10\% bovine calf serum and $10 \%$ fetal bovine serum (FBS) (Invitrogen), respectively. Medium for the stabilized HeLa cells with overexpression of SOD2 was also supplemented with $0.2 \mathrm{mg} / \mathrm{ml}$ G418 (Life Technologies Inc.). Medium for U87 was supplemented with 10\% FBS, $1 \mathrm{mM}$ sodium pyruvate, and $2 \mathrm{mM}$ glutamine without penicillin and streptomycin.

Silencing beclin-1, atg-7, or sod-2 genes by siRNA. The methods for transfection of siRNA into cells and for the treatment of cells have been described in our previous studies. ${ }^{17,18}$

Flow cytometric quantification of AVOs. The method is same as described in our previous studies. ${ }^{17,18}$

Staining autophagosomes with GFP-LC3. The method is same as described in our previous studies. ${ }^{17,18}$ Cells transfected with GFP alone plasmid did not show punctate green dots (vacuoles) when treated with starvation, mETC inhibitors, 2-ME or $\mathrm{H}_{2} \mathrm{O}_{2}$, and therefore the results have not been demonstrated in this study. Only the results of cells transfected with GFP-LC3 plasmid have been demonstrated.

Flow cytometric analysis of ROS. Reactive oxygen species generation was determined by flow cytometry after cells were stained with DHE or CMH2DCFDA . DHE and CM-H2DCFDA are used to specifically detect the generation of intracellular $\mathrm{O}_{2}^{\bullet-}$ and $\mathrm{H}_{2} \mathrm{O}_{2}$, respectively. ${ }^{27}$ DHE is oxidized to red fluorescent ethidium by $\mathrm{O}_{2}^{\bullet-17,18,27}$ and CM-H2DCFDA is oxidized to green fluorescent DCF (dichlorofluorescein) by $\mathrm{H}_{2} \mathrm{O}_{2}{ }^{27}$ For staining of cells, cells were centrifuged and the pellet was resuspended in $0.2 \mathrm{ml}$ PBS in an Eppendorf tube. DHE with a final concentration of $3.2 \mu \mathrm{M}$ or CM-H2DCFDA with a final concentration of $5 \mu \mathrm{M}$ was added into the cell suspension and was gently mixed. The mixture was incubated in dark in a water bath at $37^{\circ} \mathrm{C}$ for $15 \mathrm{~min}$. Then, the cell suspension was transferred into a $5 \mathrm{ml} \mathrm{FALCON} \mathrm{FACS} \mathrm{tube} \mathrm{and} \mathrm{analyzed} \mathrm{on} \mathrm{a} \mathrm{flow} \mathrm{cytometer} \mathrm{using} \mathrm{CellQuest}$ software (Becton Dickinson, San Jose, CA, USA) within 10 min. Alternatively, cells can be stained with DHE or CM-H2DCFDA for 15 min before trypsinization (for attachment cells). Actually, these two cell staining methods gave similar results (Supplementary data Figure S1). In this study, ROS have been measured by staining cells with DHE or CM-H2DCFDA after trypsinizing cells, removing trypsin, and resuspending cells in PBS.

Flow cytometric analysis of cell death. Cell death was detected by measuring the plasma membrane permeability to Trypan blue as described previously. ${ }^{18}$ Briefly, cell pellet was collected and resuspended in $200 \mu$ l PBS in an FACS tube. Then, Trypan blue with a final concentration of $0.04 \%$ was added into the cell suspension. Then cells were stained for $5 \mathrm{~min}$ at room temperature and analyzed on a flow cytometer using CellQuest software (Becton Dickinson). Histogram data on log scale were collected on the red filter ( $675 \mathrm{~nm}$, FL3-H). Two peaks in a histograph could be observed. The first peak represents viable cells, which were dimly fluorescent and not permeable to Trypan blue. The second peak represents dead cells, which were brightly fluorescent and permeable to Trypan blue. Results were confirmed by staining cells with $\mathrm{AO}$ and ethidium bromide and counting cells under a fluorescent microscope as described previously. ${ }^{17,18}$ 
Western blot analysis. Western blot analysis was performed as stated previously. ${ }^{17,18}$ Tris-glycine SDS-PAGE was used, except for the detection of conversion of LC3-I (18 kDa, cytoplasmic form) to CL3-II (16 kDa, preautophagosomal and autophagosomal membrane-bound form), where Tris-Tricine SDSPAGE was used. To determine autophagy flux, we used the lysosomal inhibitor $\mathrm{NH}_{4} \mathrm{Cl}$ at $30 \mathrm{mM}$ to treat cells before LC3-II western blot was performed. Densitometry was performed using QuantityOne software (Bio-Rad).

Statistical analysis. All experiments were repeated at least three times and each experiment was carried out at least by duplicates. The data were expressed as means \pm S.D. (standard deviation) $(n \geqslant 3)$. Statistical analysis was performed by using Student's $t$-test employing at least three independent data points. The criterion for statistical significance was $P<0.05$. The software used was Excel or Sigma blot.

Acknowledgements. The work was supported by a grant from CancerCare Manitoba Foundation. YC was supported by a post-doctoral fellowship from Manitoba Health Research Council (MHRC). MBA was supported by a US Army Department of Defense Breast Cancer Research Program Predoctoral Traineeship Award. SBG is a Manitoba Research Chair supported by MHRC.

1. Levine B, Yuan J. Autophagy in cell death: an innocent convict? J Clin Invest 2005; 115 2679-2688.

2. Azad MB, Chen Y, Gibson SB. Regulation of autophagy by reactive oxygen species (ROS): implications for cancer progression and treatment. Antioxid Redox Signal 2008; 11 777-790.

3. Chen Y, Gibson SB. Is mitochondrial generation of reactive oxygen species a trigger for autophagy? Autophagy 2008; 4: 246-248.

4. Ozben T. Oxidative stress and apoptosis: impact on cancer therapy. J Pharm Sci 2007; 96 2181-2196.

5. Bridges KR. Ascorbic acid inhibits lysosomal autophagy of ferritin. J Biol Chem 1987; 262: 14773-14778.

6. Lemasters JJ, Nieminen AL, Qian T, Trost LC, Elmore SP, Nishimura $Y$ et al. The mitochondrial permeability transition in cell death: a common mechanism in necrosis, apoptosis and autophagy. Biochim Biophys Acta 1998; 1366: 177-196.

7. Kirkland RA, Adibhatla RM, Hatcher JF, Franklin JL. Loss of cardiolipin and mitochondria during programmed neuronal death: evidence of a role for lipid peroxidation and autophagy. Neuroscience 2002; 115: 587-602.

8. Gómez-Santos C, Ferrer I, Santidrián AF, Barrachina M, Gil J, Ambrosio S. Dopamine induces autophagic cell death and alpha-synuclein increase in human neuroblastoma SH-SY5Y cells. J Neurosci Res 2003; 73: 341-350.

9. Djavaheri-Mergny $M$, Amelotti $M$, Mathieu J, Besançon $F$, Bauvy $C$, Souquère $S$ et al. $\mathrm{NF}-\kappa \mathrm{B}$ activation represses tumor necrosis factor- $\alpha$-induced autophagy. $J$ Biol Chem 2006; 281: 30373-30382.

10. Kiffin R, Bandyopadhyay U, Cuervo AM. Oxidative stress and autophagy. Antioxid Redox Signal 2006; 8: 152-162.

11. Kissová I, Deffieu M, Samokhvalov V, Velours G, Bessoule JJ, Manon S et al. Lipid oxidation and autophagy in yeast. Free Radic Biol Med 2006; 41: 1655-1661.

12. Byun YJ, Lee SB, Kim DJ, Lee HO, Son MJ, Yang CW et al. Protective effects of vacuolar $\mathrm{H}+-\mathrm{ATPase} \mathrm{c}$ on hydrogen peroxide-induced cell death in $\mathrm{C} 6$ glioma cells. Neurosci Lett 2007; 425: 183-187.
13. Kim EH, Sohn S, Kwon HJ, Kim SU, Kim MJ, Lee SJ et al. Sodium selenite induces superoxide-mediated mitochondrial damage and subsequent autophagic cell death in malignant glioma cells. Cancer Res 2007; 67: 6314-6324.

14. Kunchithapautham $\mathrm{K}$, Rohrer B. Apoptosis and autophagy in photoreceptors exposed to oxidative stress. Autophagy 2007; 3: 433-441.

15. Scherz-Shouval R, Shvets E, Fass E, Shorer H, Gil L, Elazar Z. Reactive oxygen species are essential for autophagy and specifically regulate the activity of Atg4. EMBO J 2007; 26: 1749-1760.

16. Xiong $\mathrm{Y}$, Contento AL, Nguyen $\mathrm{PQ}$, Bassham DC. Degradation of oxidized proteins by autophagy during oxidative stress in Arabidopsis. Plant Physiol 2007; 143: 291-299.

17. Chen Y, McMillan-Ward E, Kong J, Israels SJ, Gibson SB. Mitochondrial electrontransport-chain inhibitors of complexes I and II induce autophagic cell death mediated by reactive oxygen species. J Cell Sci 2007; 120: 4155-4166.

18. Chen Y, McMillan-Ward E, Kong J, Israels SJ, Gibson SB. Oxidative stress induces autophagic cell death independent of apoptosis in transformed and cancer cells. Cell Death Differ 2008; 15: 171-182.

19. Chen F, Wang CC, Kim E, Harrison LE. Hyperthermia in combination with oxidative stress induces autophagic cell death in HT-29 colon cancer cells. Cell Biol Int 2008; 32: 715-723.

20. Dadakhujaev S, Noh HS, Jung EJ, Hah YS, Kim CJ, Kim DR. The reduced catalase expression in TrkA-induced cells leads to autophagic cell death via ROS accumulation. Exp Cell Res 2008; 314: 3094-3106.

21. Pyo JO, Nah J, Kim HJ, Lee HJ, Heo J, Lee $\mathrm{H}$ et al. Compensatory activation of ERK1/2 in Atg5-deficient mouse embryo fibroblasts suppresses oxidative stress-induced cell death. Autophagy 2008; 4: 315-321.

22. Yang J, Wu LJ, Tashino S, Onodera S, Ikejima T. Reactive oxygen species and nitric oxide regulate mitochondria-dependent apoptosis and autophagy in evodiamine-treated human cervix carcinoma HeLa cells. Free Radic Res 2008; 42: 492-504.

23. Huang P, Feng L, Oldham EA, Keating MJ, Plunkett W. Superoxide dismutase as a target for the selective killing of cancer cells. Nature 2000; 407: 390-395.

24. Azad MB, Chen Y, Henson ES, Cizeau J, McMillan-Ward E, Israels SJ et al. Hypoxia induces autophagic cell death in apoptosis-competent cells through a mechanism involving BNIP3. Autophagy 2008; 4: 195-204.

25. Mizushima N, Yoshimori T. How to interpret LC3 immunoblotting. Autophagy 2007; 3 : 542-545.

26. Klionsky DJ, Abeliovich H, Agostinis P, Agrawal DK, Aliev G, Askew DS et al. Guidelines for the use and interpretation of assays for monitoring autophagy in higher eukaryotes. Autophagy 2008; 4: 151-175

27. Gao N, Rahmani M, Dent P, Grant S. 2-Methoxyestradiol-induced apoptosis in human leukemia cells proceeds through a reactive oxygen species and Akt-dependent process. Oncogene 2005; 24: 3797-3809

28. Hagen T, D'Amico G, Quintero M, Palacios-Callender M, Hollis V, Lam F et al. Inhibition of mitochondrial respiration by the anticancer agent 2-methoxyestradiol. Biochem Biophys Res Commun 2004; 322: 923-929.

29. Kulisz A, Chen N, Chandel NS, Shao Z, Schumacker PT. Mitochondrial ROS initiate phosphorylation of p38 MAP kinase during hypoxia in cardiomyocytes. Am J Physiol Lung Cell Mol Physiol 2002; 282: L1324-L1329.

30. Nonn L, Berggren M, Powis G. Increased expression of mitochondrial peroxiredoxin-3 (thioredoxin peroxidase-2) protects cancer cells against hypoxia and drug-induced hydrogen peroxide-dependent apoptosis. Mol Cancer Res 2003; 1: 682-689.

31. Li J, Li Q, Xie C, Zhou H, Wang Y, Zhang $\mathrm{N}$ et al. Beta-actin is required for mitochondria clustering and ROS generation in TNF-induced, caspase-independent cell death. J Cell Sci 2004; 117: 4673-4680.

32. Mizushima N, Levine B, Cuervo AM, Klionsky DJ. Autophagy fights disease through cellular self-digestion. Nature 2008; 451: 1069-1075.

33. Radi R, Turrens JF, Chang LY, Bush KM, Crapo JD, Freeman BA. Detection of catalase in rat heart mitochondria. J Biol Chem 1991; 266: 22028-22034. 